\title{
Modeling atmospheric ammonia and ammonium using a stochastic Lagrangian air quality model (STILT-Chem v0.7)
}

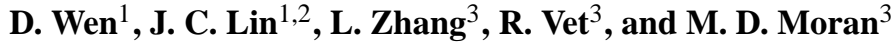 \\ ${ }^{1}$ Waterloo Atmosphere-Land Interactions Research Group, Department of Earth and Environmental Sciences, \\ University of Waterloo, Canada \\ ${ }^{2}$ Department of Atmospheric Sciences, University of Utah, USA \\ ${ }^{3}$ Air Quality Research Division, Science and Technology Branch, Environment Canada, Canada
}

Correspondence to: J. C. Lin (john.lin@utah.edu)

Received: 10 July 2012 - Published in Geosci. Model Dev. Discuss.: 12 September 2012

Revised: 27 January 2013 - Accepted: 15 February 2013 - Published: 11 March 2013

\begin{abstract}
A new chemistry module that simulates atmospheric ammonia $\left(\mathrm{NH}_{3}\right)$ and ammonium $\left(\mathrm{NH}_{4}^{+}\right)$was incorporated into a backward-in-time stochastic Lagrangian air quality model (STILT-Chem) that was originally developed to simulate the concentrations of a variety of gas-phase species at receptors. STILT-Chem simulates the transport of air parcels backward in time using ensembles of fictitious particles with stochastic motions, while accounting for emissions, deposition and chemical transformation forward in time along trajectories identified by the backward-in-time simulations. The incorporation of the new chemistry module allows the model to simulate not only gaseous species, but also multi-phase species involving $\mathrm{NH}_{3}$ and $\mathrm{NH}_{4}^{+}$. The model was applied to simulate concentrations of $\mathrm{NH}_{3}$ and particulate $\mathrm{NH}_{4}^{+}$at six sites in the Canadian province of Ontario for a six-month period in 2006. The model-predicted concentrations of $\mathrm{NH}_{3}$ and particulate $\mathrm{NH}_{4}^{+}$were compared with observations, which show broad agreement between simulated concentrations and observations. Since the model is based on back trajectories, the influence of each major process such as emission, deposition and chemical conversion on the concentration of a modeled species at a receptor can be determined for every upstream location at each time step. This makes it possible to quantitatively investigate the upstream processes affecting receptor concentrations. The modeled results suggest that the concentrations of $\mathrm{NH}_{3}$ at those sites were significantly and frequently affected by Ohio, Iowa, Minnesota, Michigan, Wisconsin, southwestern Ontario and nearby areas. $\mathrm{NH}_{3}$ is mainly contributed by emission sources whereas particulate $\mathrm{NH}_{4}^{+}$is mainly con-
\end{abstract}

tributed by the gas-to-aerosol chemical conversion of $\mathrm{NH}_{3}$. Dry deposition is the largest removal process for both $\mathrm{NH}_{3}$ and particulate $\mathrm{NH}_{4}^{+}$. This study revealed the contrast between agricultural versus forest sites. Not only were emissions of $\mathrm{NH}_{3}$ higher, but removal mechanisms (especially chemical loss for $\mathrm{NH}_{3}$ and dry deposition for $\mathrm{NH}_{4}^{+}$) were less efficient for agricultural sites. This combination explains the significantly higher concentrations of $\mathrm{NH}_{3}$ and particulate $\mathrm{NH}_{4}^{+}$observed at agricultural sites.

\section{Introduction}

Ammonia $\left(\mathrm{NH}_{3}\right)$ is the primary basic gas in the atmosphere. $\mathrm{NH}_{3}$ acts as a major agent in neutralizing acids in the atmosphere and plays an important role in aerosol formation. Thus $\mathrm{NH}_{3}$ has major impacts on human health, acid deposition, atmospheric visibility, and radiative forcing. The significant sources of $\mathrm{NH}_{3}$ are animal waste, ammonification of humus followed by emission from soils, losses of $\mathrm{NH}_{3}$-based fertilizers from soils, and industrial emissions (Asman et al., 1998). In the atmosphere, $\mathrm{NH}_{3}$ is subject to transport and diffusion, removal by dry and wet deposition, and transformation to aerosol-bound $\mathrm{NH}_{4}^{+}$in reactions with acid gases and aerosols. Excessive deposition of atmospheric $\mathrm{NH}_{3}$ and $\mathrm{NH}_{4}^{+}$may lead to soil acidification and damage to sensitive species and ecosystem health (van Bremen et al., 1982; Morris, 1991).

Measurements of $\mathrm{NH}_{3}$ and $\mathrm{NH}_{4}^{+}$concentrations from monitoring programmes not only provide information about 
actual levels and trends of $\mathrm{NH}_{3}$ in the environment, but also form the basis of our understanding of the physical and chemical processes governing the fate of $\mathrm{NH}_{3}$. However, measurements alone are usually insufficient for a complete understanding of those processes due to the limited number of monitoring locations and the inability to observe processes of interest as an air parcel is advected over the landscape. Modeling atmospheric $\mathrm{NH}_{3}$ yields additional insights by providing information about locations not covered by the monitoring network as well as processes that are not measured explicitly. Well-tested and validated air quality models are thus highly useful in the assessment and interpretation of ambient $\mathrm{NH}_{3}$ and $\mathrm{NH}_{4}^{+}$measurements.

Extensive efforts have been made to modeling studies of atmospheric $\mathrm{NH}_{3}$ using different models either in an Eulerian framework (Brandt et al., 2012; Berge, 2008; Reis et al., 2011; Wu et al., 2008; Makar et al., 2009; Sakurai et al., 2005) or in a Lagrangian framework. Although the Eulerian approach is powerful and widely used for elucidating the chemical and physical mechanism in the atmosphere, the Lagrangian approach demonstrates key advantages in presenting sub-grid scale process, minimizing numerical diffusion, artificial dilution and computing resources. The Lagrangian approach has been widely adopted in various models in atmospheric ammonia modeling such as the FRAME model (Singles et al., 1998; Kryza et al., 2011; Zhang et al., 2011), the TREND model (Asman and van Jaarsveld, 1992; Asman, 2001), the ACDEP model (Hertel et al., 1995, 2002, 2003; Gyldenkœrne et al., 2005; de Leeuw et al., 2003; Skjøth et al., 2002, 2004, 2011), The TERN model (ApSimon et al., 1994), and the NAME model (Redington and Derwent, 2002). Most existing Lagrangian models for atmospheric ammonia modeling are either box-based models or use a simplified dry chemical scheme. In this study, we attempt to model atmospheric ammonia using a stochastic time-inverted Lagrangian particle model in which a comprehensive dry chemical scheme (Carbon Bond IV) and a backtrajectory method are used. Plumes in Lagrangian particle models are represented by a large number of fictitious particles, which move with random trajectories to represent atmospheric turbulence. Particle models are able to account in detail for three-dimensional variations in the wind field and the effects of turbulent dispersion. Thus these particle models are particularly useful for simulating the effect of highly variable emissions on atmospheric concentrations in complex dispersion scenarios.

The main goals of this study are (1) to develop a stochastic back-trajectory based air quality model for simulating atmospheric $\mathrm{NH}_{3}$; (2) to use this model to interpret $\mathrm{NH}_{3}$ and particulate $\mathrm{NH}_{4}^{+}\left(p-\mathrm{NH}_{4}^{+}\right)$concentrations at monitoring sites; and (3) to quantitatively assess the contributions of various sources, sinks, and processes to the sites.

\section{Model description}

The model used in this study is a backward-in-time stochastic Lagrangian air quality model (STILT-Chem) (Wen et al., 2012), built from the Stochastic Time-Inverted Lagrangian Transport model (STILT; see http://www.stilt-model.org) (Lin et al., 2003), which in turn was based on the HYbrid Single-Particle Lagrangian Integrated Trajectory (HYSPLIT) model (Draxler and Hess, 1997). STILT-Chem is an effective tool to investigate the upstream influences of emission, deposition and chemical conversion on receptors. The simulation of the model begins with a stochastic backtrajectory simulation, followed by forward calculations that determine tracer concentrations along the generated back trajectories (Wen et al., 2012). In the back-trajectory simulation, numerous particles, each representing an air parcel, are released from a receptor and transported backward in time for a specific period. Each particle is transported by both interpolated mean wind fields as well as stochastic velocities representing turbulent eddies. After back trajectories are calculated, the concentrations of modeled species are initialized at the endpoint of each back trajectory using values output from a global chemical transport model (Sect. 3.2.1). The initial parcel concentrations are then evolved forward in time along each trajectory to take into consideration the influences of emissions, deposition, mixing, and chemical transformation. Although the STILT-Chem model is capable of simulating a variety of gas-phase species in the atmosphere using the Carbon Bond IV (CB4) mechanism (Gery et al., 1989), atmospheric $\mathrm{NH}_{3}$ was originally omitted by the CB4 due to the involvement of multi-phase reactions in its dominant atmospheric chemical processes. In this study, we have added an additional chemistry module into STILT-Chem, allowing it to simulate atmospheric $\mathrm{NH}_{3}$ and particulate $\mathrm{NH}_{4}^{+}$, in addition to the original CB4-related gas-phase species. The treatment of transport and diffusion, emissions, deposition, and chemistry for the CB4 species in the model has been described thoroughly by Wen et al. (2012). Hence in this paper a detailed and comprehensive description is only presented for the new implementation of $\mathrm{NH}_{3}$ and $\mathrm{NH}_{4}^{+}$and an alternative dry deposition scheme in STILT-Chem.

\subsection{Transport and diffusion}

The STILT-Chem model simulates the transport of air parcels, represented as fictitious particles, backward in time. Each fictitious particle is advected with mean wind velocities as well as stochastic velocities parameterized to represent the effect of turbulent transport. The effect of the turbulence is simulated by adding a random velocity to the mean motion for each particle. This random velocity is a function of the turbulence intensity and is different for each particle. Turbulent strengths were diagnosed from meteorological fields (Sect. 3.2) using the Hanna scheme (Hanna, 1982). The 
detailed treatment of transport and diffusion in the model can been found in Lin et al. (2003) and Draxler and Hess (1997).

\subsection{Emissions}

The molar mixing ratio change of a species in a particle due to surface emissions is calculated using a "footprint" concept and emission fluxes. A footprint $f\left(\boldsymbol{x}_{\mathrm{r}}, t_{\mathrm{r}} \mid x_{i}, y_{j}, t_{m}\right)$, in units of ppm $\left(\mu \text { mole } \mathrm{m}^{-2} \mathrm{~s}^{-1}\right)^{-1}$, which is calculated in a backtrajectory simulation, represents the sensitivity of the molar mixing ratio arriving at its receptor at location $\boldsymbol{x}_{\mathrm{r}}$ at time $t_{\mathrm{r}}$ to the surface flux $F\left(x_{i}, y_{j}, t_{m}\right)$ from location $x_{i}, y_{j}$ at time $t_{m}$ (Lin et al., 2003; Wen et al., 2012, 2011). Thus it is a measure of the contribution from a source of unit strength located at $x_{i}, y_{j}$ at time $t_{m}$ to the mixing ratio at the receptor. The footprint is derived from the local density of particles by counting the number of particles (out of total number $N_{\text {tot }}$ ) in surface-influenced boxes and determining the amount of time $\Delta t_{p, i, j, k}$ each particle $p$ spends in each surface volume element $(i, j, k)$ during each time step. The mathematical definition of a footprint (Lin et al., 2003) is given by

$f\left(\boldsymbol{x}_{\mathrm{r}}, t_{\mathrm{r}} \mid x_{i}, y_{j}, t_{m}\right)=\frac{m_{\mathrm{air}}}{h \bar{\rho}\left(x_{i}, y_{j}, t_{m}\right)} \frac{1}{N_{\mathrm{tot}}} \sum_{p=1}^{N_{\mathrm{tot}}} \Delta t_{p, i, j, k}$,

where $m_{\text {air }}$ is the molar mass of air, $h$ is the height below which turbulent mixing is strong enough to mix the surface flux thoroughly, and $\bar{\rho}\left(x_{i}, y_{j}, t_{m}\right)$ is the average air density below $h$.

The molar mixing ratio change $\Delta Q_{s, p}\left(\boldsymbol{x}_{\mathrm{r}}, t_{\mathrm{r}} \mid x_{i}, y_{j}, t_{m}\right)$ of the $s$-th species in the $p$-th particle arriving at its receptor at time $t_{\mathrm{r}}$ due to a surface emission flux $F\left(x_{i}, y_{j}, t_{m}\right)$ $\left(\mu\right.$ mole $\left.\mathrm{m}^{-2} \mathrm{~s}^{-1}\right)$ is incremented whenever the parcel dips below a specific height $h$, which is determined in STILTChem as a fraction of the PBL height (Lin et al., 2003). The fraction was set to 0.5 in this study. The mixing ratio change at the receptor is given by

$\Delta Q_{s, p}\left(\boldsymbol{x}_{\mathrm{r}}, t_{\mathrm{r}} \mid x_{i}, y_{j}, t_{m}\right)=f\left(\boldsymbol{x}_{\mathrm{r}}, t_{\mathrm{r}} \mid x_{i}, y_{j}, t_{m}\right) F\left(x_{i}, y_{j}, t_{m}\right)$

This footprint formulation is applied for emissions at the surface. For emissions at altitude (e.g., smokestacks) we dilute the emission throughout the grid box in which the higher altitude emission is found. Therefore, the mixing ratio change at the receptor for an emission at altitude is given as follows (Wen et al., 2011):

$\Delta Q_{s, p}\left(\boldsymbol{x}_{\mathrm{r}}, t_{\mathrm{r}} \mid x_{i}, y_{j}, z_{k}, t_{m}\right)=\frac{D\left(x_{i}, y_{j}, z_{k}, t_{m}\right)}{N_{\mathrm{tot}}} \sum_{p=1}^{N_{\mathrm{tot}}} \Delta t_{p, i, j, k}$

$=F\left(x_{i}, y_{j}, z_{k}, t_{m}\right) \frac{m_{\mathrm{air}}}{\Delta z \bar{\rho}\left(x_{i}, y_{j}, z_{k}, t_{m}\right)} \frac{1}{N_{\text {tot }}} \sum_{p=1}^{N_{\text {tot }}} \Delta t_{p, i, j, k}$,

where $F\left(x_{i}, y_{j}, z_{k}, t_{m}\right)$ is the emission flux in a grid box $(i, j, k)$ at time $t_{m} . D\left(x_{i}, y_{j}, z_{k}, t_{m}\right)$ represents the dilution of emission flux in the grid box with a thickness of $\Delta z$. Molar mixing ratios (ppm) are converted into concentrations $\left(\mu \mathrm{g} \mathrm{m}^{-3}\right)$ afterwards by multiplying with air density. Details concerning the North American emissions that were used in this study are provided in Sect. 3.2.2.

\subsection{Gas-phase chemistry for CB4 species}

The CB4 gas-phase chemistry mechanism (Gery et al., 1989) is used in the model to simulate chemical transformations for gas-phase species. The CB4 mechanism was originally developed primarily to simulate urban and regional ozone formation and is a collection of gas-phase reactions that transform reactants into products, including key intermediates. The mechanism used here is a modified version that contains 92 reactions involving 38 chemical species (Stein et al., 2000). The differential equations of this mechanism are solved using a modified Gear method (Gear, 1971; Press et al., 1992; Spellmann and Hindmarsh, 1975). The photolysis rate constants required to calculate the chemical transformations are computed as a function of the solar zenith angle, cloud cover, and chemical species for each particle at each time step. $\mathrm{NH}_{3}$ is not included in the standard CB4 mechanism.

\subsection{Implementing chemistry for $\mathrm{NH}_{3}$ and $\mathrm{NH}_{4}^{+}$}

$\mathrm{NH}_{3}$ can react with $\mathrm{O}_{2}, \mathrm{HCl}, \mathrm{OH}$ radical, nitric acid vapor, and sulfuric acid in the atmosphere. However, not all gasphase reactions of $\mathrm{NH}_{3}$ are important (Seinfeld and Pandis, 2006) due to either small reaction constants or low concentrations of reactants. The dominant reactions of $\mathrm{NH}_{3}$ in the atmosphere are with nitric acid vapor and sulfuric acid (Seinfeld and Pandis, 2006). Thus only reactions with nitric acid vapor and sulfuric acid are considered in this study.

\subsubsection{Reaction with $\mathrm{H}_{2} \mathrm{SO}_{4}$}

$\mathrm{NH}_{3}+\mathrm{H}_{2} \mathrm{SO}_{4} \rightarrow \mathrm{NH}_{4} \mathrm{HSO}_{4}(\mathrm{~s})$

$\mathrm{NH}_{3}+\mathrm{NH}_{4} \mathrm{HSO}_{4}(\mathrm{~s}) \rightarrow\left(\mathrm{NH}_{4}\right)_{2} \mathrm{SO}_{4}(\mathrm{~s})$

If sulfuric acid $\left(\mathrm{H}_{2} \mathrm{SO}_{4}\right)$ is present in the atmosphere, gaseous $\mathrm{NH}_{3}$ will practically always react with $\mathrm{H}_{2} \mathrm{SO}_{4}$ in either gas or aerosol phase. This process is considered irreversible. $\mathrm{NH}_{3}$ is expected to react instantaneously to fully neutralize the available $\mathrm{H}_{2} \mathrm{SO}_{4}$. The formation of ammonium sulfate $\left(\left(\mathrm{NH}_{4}\right)_{2} \mathrm{SO}_{4}\right)$ and ammonuim bisulfate $\left(\mathrm{NH}_{4} \mathrm{HSO}_{4}\right)$ is thus only limited by the availability of either $\mathrm{NH}_{3}$ or $\mathrm{H}_{2} \mathrm{SO}_{4}$. For simplicity, an equal mixture of $\left(\mathrm{NH}_{4}\right)_{2} \mathrm{SO}_{4}$ and $\mathrm{NH}_{4} \mathrm{HSO}_{4}$ was assumed for ammonium sulfate production from this reaction (EMEP, 1998) in the model, although more complex inorganic thermodynamic equilibrium schemes do not make this assumption (Nenes et al., 1999; Wexler and Clegg, 2002).

The availability of $\mathrm{H}_{2} \mathrm{SO}_{4}$ is mainly determined by its emissions, deposition, and chemical conversions. The 
formation of $\mathrm{H}_{2} \mathrm{SO}_{4}$ from gas-phase chemical processes is calculated by the $\mathrm{CB} 4$ mechanism. The major aqueous-phase formation is from the conversion of dissolved $\mathrm{SO}_{2}$ and is estimated following an approach from Rolph et al. $(1992,1993)$.

When $\mathrm{SO}_{2}$ dissolves in water, three species are formed: $\mathrm{H}_{2} \mathrm{SO}_{3}, \mathrm{HSO}_{3}^{-}$, and $\mathrm{SO}_{3}^{2-}$. These three species can be oxidized by hydrogen peroxide $\left(\mathrm{H}_{2} \mathrm{O}_{2}\right), \mathrm{O}_{3}, \mathrm{OH}^{-}$, or $\mathrm{O}_{2}$ in the presence of catalysts $\left(\mathrm{Fe}^{3+}, \mathrm{Mn}^{2+}\right)$. However, only the oxidation by $\mathrm{H}_{2} \mathrm{O}_{2}$ is the most important (Hoffmann and Calvert, 1985) when $\mathrm{pH} \leq 5$. Since this is a common $\mathrm{pH}$ value of rain water (Charlson and Rodhe, 1982), we assume that this oxidation reaction is the only aqueous-phase reaction affecting sulfuric acid production from dissolved $\mathrm{SO}_{2}$. Thus, the concentration changes of gaseous $\mathrm{SO}_{2}$ and aqueous sulfuric acid due to the aqueous-phase oxidation of dissolved $\mathrm{SO}_{2}$ can be determined as (Rolph et al., 1992)

$-\frac{d\left[\mathrm{SO}_{2}\right]}{\mathrm{d} t}=k_{\mathrm{w}}\left[\mathrm{SO}_{2}\right]$

and

$\frac{d\left[\left(\mathrm{SO}_{4}^{2-}\right)_{\mathrm{w}}\right]}{\mathrm{d} t}=k_{\mathrm{w}}\left[\mathrm{SO}_{2}\right]$,

where the rate constant $k_{\mathrm{w}}$ is a function of the air concentration of $\mathrm{H}_{2} \mathrm{O}_{2}$, the liquid water content in the cloud $(L)$, and the air concentration of $\mathrm{SO}_{2}$.

$k_{\mathrm{w}}=41.57 L\left[\mathrm{H}_{2} \mathrm{O}_{2}\right] e^{-0.233\left[\mathrm{SO}_{2}\right]}$

The air concentration of $\mathrm{H}_{2} \mathrm{O}_{2}$ required in Eq. (6) is computed and provided by the CB4 mechanism. $L$ is set to $0.9 \mathrm{~g} \mathrm{~m}^{-3}$.

\subsubsection{Reaction with $\mathrm{HNO}_{3}$}

In the atmosphere, $\mathrm{NH}_{3}$ and $\mathrm{HNO}_{3}$ vapor can react to form ammonium nitrate $\left(\mathrm{NH}_{4} \mathrm{NO}_{3}\right)$ under conditions when excess $\mathrm{NH}_{3}$ is available after reacting with $\mathrm{H}_{2} \mathrm{SO}_{4}$.

$\mathrm{NH}_{3}(\mathrm{~g})+\mathrm{HNO}_{3}(\mathrm{~g}) \rightleftharpoons \mathrm{NH}_{4} \mathrm{NO}_{3}(\mathrm{~s}, \mathrm{aq})$

This is a major route of $\mathrm{NH}_{3}$ to form particle nitrate. The production of this reaction, controlled by the ambient temperature $(T)$ and relative humidity $(\mathrm{RH})$, may exist as a solid or as an aqueous solution.

$\mathrm{NH}_{4} \mathrm{NO}_{3}$ exists as a solid if $\mathrm{RH}$ is less than the deliquescence relative humidity $\left(\mathrm{RH}_{\mathrm{d}}\right)$ (Mozurkewich, 1993):

$\ln \mathrm{RH}_{\mathrm{d}}=\frac{618.3}{T}-2.551$

where $\mathrm{RH}_{\mathrm{d}}$ is a fraction and $T$ is in Kelvins. The corresponding equilibrium reaction is

$\mathrm{NH}_{3}(\mathrm{~g})+\mathrm{HNO}_{3}(\mathrm{~g}) \rightleftharpoons \mathrm{NH}_{4} \mathrm{NO}_{3}(\mathrm{~s})$.
The dissociation constant $K_{p}(T)$ of the Reaction (R4) is equal to the product of the partial pressures of $\mathrm{NH}_{3}$ and $\mathrm{HNO}_{3}$, and can be determined by (Mozurkewich, 1993)

$\ln K_{p}=118.87-\frac{24084}{T}-6.025 \ln (T)$

The equilibrium constant $K_{\text {eq }}$ of the Reaction (R4), in this case, is equal to $K_{p}$.

If $\mathrm{RH}$ is greater than $\mathrm{RH}_{\mathrm{d}}, \mathrm{NH}_{4} \mathrm{NO}_{3}$ will be in the aqueous state. The corresponding dissociation reaction is then

$\mathrm{NH}_{3}(\mathrm{~g})+\mathrm{HNO}_{3}(\mathrm{~g}) \rightleftharpoons \mathrm{NH}_{4}^{+}+\mathrm{NO}_{3}^{-}$.

In this case, the equilibrium constant, $K_{\text {eq }}(T)$, is given by (Mozurkewich, 1993)

$K_{\text {eq }}=\left[P_{1}-P_{2}\left(1-\frac{\mathrm{RH}}{100}\right)+P_{3}\left(1-\frac{\mathrm{RH}}{100}\right)^{2}\right]\left(1-\frac{\mathrm{RH}}{100}\right)^{1.75} K_{p}$

where both $K_{p}$ and $K_{\text {eq }}$ are in units of (molecules $\left.\mathrm{cm}^{-3}\right)^{2}$ and RH is in percent. $P_{1}, P_{2}$ and $P_{3}$ are calculated as follows (Mozurkewich, 1993):

$\ln P_{1}=-135.94+\frac{8763}{T}+19.12 \ln (T)$
$\ln P_{2}=-122.65+\frac{9969}{T}+16.22 \ln (T)$
$\ln P_{3}=-182.61+\frac{13875}{T}+24.46 \ln (T)$.

Equilibrium concentrations of gaseous $\mathrm{NH}_{3}$ and $\mathrm{HNO}_{3}$, and the resulting concentration of solid or aqueous $\mathrm{NH}_{4} \mathrm{NO}_{3}$, are calculated from fundamental thermodynamic principles. The equilibrium concentration of $\mathrm{NH}_{3}$ is given by the Equation (EMEP, 1998):

$\left[\mathrm{NH}_{3 \mathrm{eq}}\right]=\frac{\left[\mathrm{NH}_{3}\right]+\left[\mathrm{HNO}_{3}\right]}{2}+\sqrt{\frac{\left(\left[\mathrm{NH}_{3}\right]-\left[\mathrm{HNO}_{3}\right]\right)^{2}}{4}+K_{\mathrm{eq}}}$

The air concentration of $\mathrm{HNO}_{3}$ from gas-phase chemical reactions is calculated by the CB4 mechanism. Heterogeneous conversion of $\mathrm{N}_{2} \mathrm{O}_{5}$ to $\mathrm{HNO}_{3}$ on the surface of aerosol particles that contain water is not included in the model. The contribution of this process to the air concentration of $\mathrm{HNO}_{3}$ is therefore neglected.

\subsection{Deposition}

The concentration change of the $s$-th species due to dry and wet deposition is expressed in terms of time constants:

$\frac{d C_{s}}{\mathrm{~d} t}=-\left(\beta_{\mathrm{d}_{s}}+\beta_{\mathrm{w}_{s}}\right) C_{s}$

where $\beta_{\mathrm{d}_{s}}$ and $\beta_{\mathrm{w}_{s}}$ are time constants for dry and wet deposition for the $s$-th species, respectively. 


\subsubsection{Dry deposition}

The time constant for dry deposition is expressed as follows:

$\beta_{\mathrm{d}_{s}}=\frac{V_{\mathrm{dry}_{s}}}{Z_{s}}$.

Dry deposition is only estimated when a particle moves into the lowest model level, the depth of which $\left(Z_{s}\right)$ is approximately $50 \mathrm{~m}$ in this study and which is assumed to be the top of the surface layer. $V_{\mathrm{dry}_{s}}\left(\mathrm{~cm} \mathrm{~s}^{-1}\right)$ is the dry deposition velocity for the $s$-th species. The dry deposition velocities of all modeled species (including gas-phase $\mathrm{CB} 4$ species, $\mathrm{NH}_{3}$, particulate $\mathrm{NH}_{4}^{+}, \mathrm{NO}_{3}^{-}$, and $\mathrm{SO}_{4}^{2+}$ ) can be either calculated or provided explicitly.

A dry deposition scheme based on the work of Wesely (1989) was used originally by the model to calculate dry deposition velocities for the modeled gaseous and aerosol species (Draxler and Hess, 1997).

In this study, we added another dry deposition approach developed by Zhang et al. (2001, 2003) (hereafter referred to as the "Zhang approach") as another option to calculate dry deposition velocities for the modeled species. The Zhang approach calculates dry deposition velocities for more than 30 gaseous species and 14 particulate species that are usually considered in air quality models. Although it employs a similar approach used in Wesely (1989), the Zhang approach incorporates vegetation density effects via leaf area index and possesses an updated representation of non-stomatal deposition pathways, including improved treatment of snow cover. In this approach, dry deposition is parameterized as a species-specific weighted combination of the deposition properties of two archetypal species: $\mathrm{O}_{3}$ and $\mathrm{SO}_{2}$. Nonstomatal resistance (including in-canopy aerodynamic resistance, soil resistance, and cuticle resistance) for $\mathrm{SO}_{2}$ and $\mathrm{O}_{3}$ is parameterized as a function of friction velocity, relative humidity, leaf area index, and canopy wetness. Nonstomatal resistance for all other species is scaled to those of $\mathrm{SO}_{2}$ and $\mathrm{O}_{3}$ based on their chemical and physical characteristics. Dry deposition of particulate species is calculated as a function of particle size (Zhang et al., 2001). The Zhang approach is formulated for 26 land-use categories and widely used by air quality models such as GEOS-chem (Alexander et al., 2005), the Comprehensive Air quality Model with Extensions (CAMx) (Nopmongcol et al., 2012), and A Unified Regional Air-quality Modeling System (AURAMS) (Zhang et al., 2002).

\subsubsection{Wet deposition}

Wet deposition is represented via loss rates computed based on precipitation rates. The wet deposition velocity for the $s$ th gas-phase species can be calculated as (Draxler and Hess, 1997)

$V_{\text {wet }_{s}}=H_{s} \mathrm{RTP}$, where $H_{S}$ is the effective Henry's Law constant of the $s$-th species, $R$ is the universal gas constant $\left(0.082 \mathrm{~atm} \mathrm{~mol} \mathrm{~K}^{-1} L\right)$, and $T$ and $P$ are, respectively, air temperature and precipitation rate in an air parcel. The gaseous wet removal time constant is given by

$\beta_{\mathrm{w}_{s}}=\frac{F_{\mathrm{t}} V_{\mathrm{wet}_{s}}}{Z_{p}}$,

where $Z_{p}$ is the depth of the meteorological layer in which the particle is found; $F_{\mathrm{t}}$ is the fraction of the layer that is below cloud top. Wet removal of all modeled gas-phase species except for $\mathrm{SO}_{2}$ was calculated using this equation.

Wet deposition of $\mathrm{SO}_{2}$ was determined following a method from Rolph et al. (1992):

$\mathrm{SO}_{2(\mathrm{aq})}=\frac{A L}{1+A L} \mathrm{SO}_{2(\mathrm{~g})}$,

where $A$ is a constant equal to 0.0533 ; $L$ is the liquid water content and set to $0.9 \mathrm{~g} \mathrm{~m}^{-3} ; \mathrm{SO}_{2}(\mathrm{~g})$ is the air concentration of $\mathrm{SO}_{2}$.

Particulate $\mathrm{SO}_{4}^{2-}$ in cloudwater consists of the $\mathrm{SO}_{4}^{2-}$ particles acting as condensation nuclei and the $\mathrm{SO}_{4}^{2-}$ formed by aqueous oxidation. The in-cloud content of particulate $\mathrm{SO}_{4}^{2-}$ can be expressed as (Rolph et al., 1992)

$\left(\mathrm{SO}_{4}^{2-}\right)_{\mathrm{ic}}=\alpha\left(\mathrm{SO}_{4}^{2-}\right)_{\mathrm{d}}+\left(\mathrm{SO}_{4}^{2-}\right)_{\mathrm{w}}$

where $\alpha=0.65$, an empirical factor, is the ratio of the activated particles to the total number of $\mathrm{SO}_{4}^{2-}$ particles. $\left(\mathrm{SO}_{4}^{2-}\right)_{\mathrm{d}}$ is the $\mathrm{SO}_{4}^{2-}$ air content due to gas-phase oxidation and emissions. $\left(\mathrm{SO}_{4}^{2-}\right)_{\mathrm{w}}$ is the amount of $\mathrm{SO}_{4}^{2-}$ formed by aqueous-phase oxidation and is calculated by

$\frac{d\left[\left(\mathrm{SO}_{4}^{2-}\right)_{\mathrm{w}}\right]}{\mathrm{d} t}=k_{\mathrm{w}}\left[\mathrm{SO}_{2}\right]$

where $k_{\mathrm{w}}$ is given in Eq. (6).

The wet removal of $\mathrm{SO}_{4}^{2-}$ within cloud is given by (Rolph et al., 1992, 1993)

$\left(\mathrm{SO}_{4}^{2-}\right)_{\mathrm{pp}}=\lambda\left(\mathrm{SO}_{4}^{2-}\right)_{\mathrm{ic}}$

where $\lambda=(18 P)^{1 / 2}$ is the scavenging ratio, representing the ratio of the $\mathrm{SO}_{4}^{2-}$ removed by precipitation to the $\mathrm{SO}_{4}^{2-}$ content in the cloud, and $P$ is the precipitation rate in $\mathrm{m} \mathrm{h}^{-1}$.

For particulate $\mathrm{NH}_{4}^{+}$and $\mathrm{NO}_{3}^{-}$, wet deposition velocity within cloud is computed as the product of scavenging ratio $S$ and precipitation rate $P$ :

$V_{\text {inc }}=S P$.

Different scavenging ratios can be defined for different pollutants. In this work we used $3.1 \times 10^{5}$ for particulate $\mathrm{NH}_{4}^{+}$ and $4.9 \times 10^{5}$ for particulate $\mathrm{NO}_{3}^{-}$(Hicks, 2005). The time constant for within-cloud removal is

$\beta_{\text {inc }}=\frac{F_{\mathrm{t}} F_{\mathrm{b}} V_{\text {inc }}}{Z_{p}}$ 


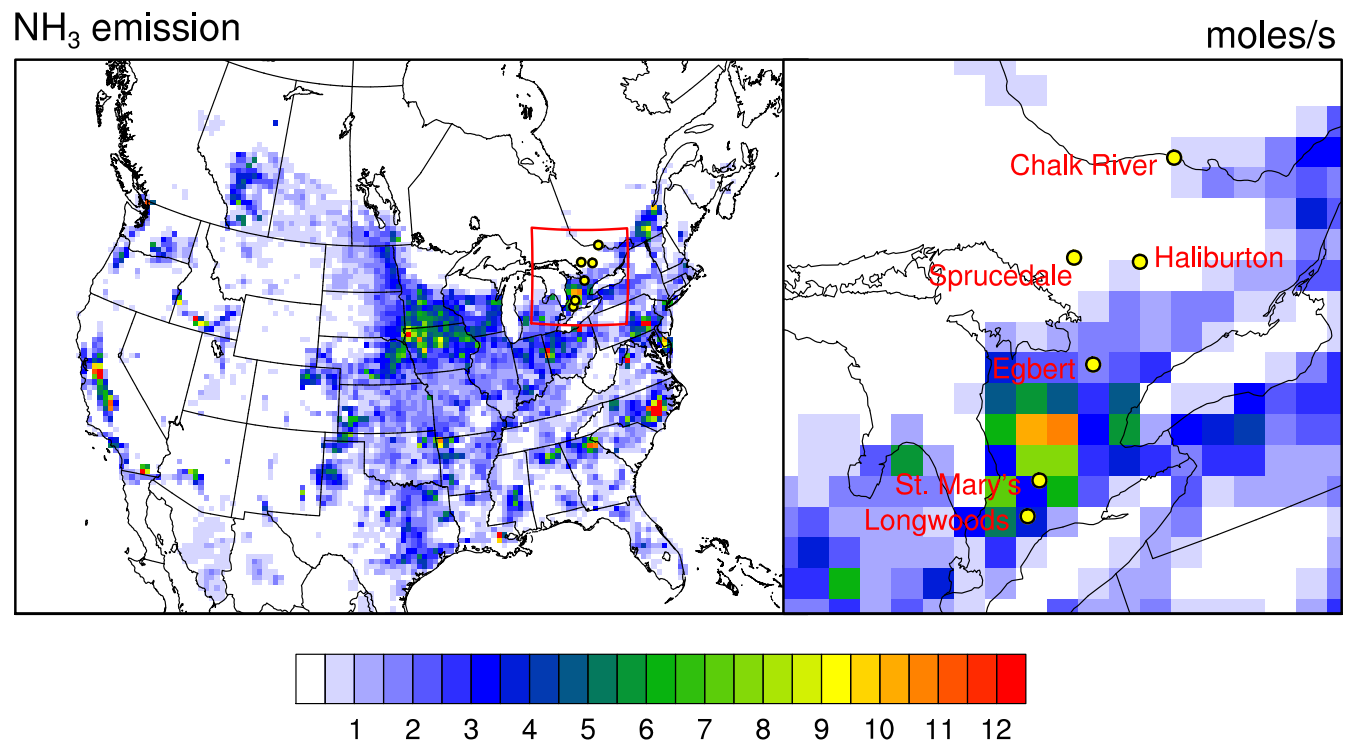

Fig. 1. Spatial distribution of gridded $\mathrm{NH}_{3}$ emissions over North America (left panel) and locations of six measurement sites and their local $\mathrm{NH}_{3}$ emission rates averaged over the simulation period (right panel, zooms into the area enclosed by red lines in the left panel).

where $F_{\mathrm{b}}$, similar to $F_{\mathrm{t}}$, is the fraction of the layer that is above cloud bottom.

Below-cloud removal for particulate $\mathrm{NH}_{4}^{+}$and $\mathrm{NO}_{3}^{-}$is defined directly as a rate constant, independent of the precipitation rate (Draxler and Hess, 1997):

$\beta_{\text {bel }}=5 \times 10^{-5}\left(1.0-F_{\mathrm{b}}\right)$.

The below-cloud scavenging of particulate $\mathrm{SO}_{4}^{2-}$ by falling droplets is expressed as (Rolph et al., 1992, 1993)

$\frac{-d\left(\mathrm{SO}_{4}^{2-}\right)}{\mathrm{d} t}=k_{\mathrm{wd}}^{\prime}\left(\mathrm{SO}_{4}^{2-}\right)_{\mathrm{d}}$,

where $k_{\mathrm{wd}}^{\prime}$ is the rate of wet removal of $\mathrm{SO}_{4}^{2-}$ and a value of $1 \times 10^{-4} \mathrm{~h}^{-1}$ is used (Rolph et al., 1992).

\section{Measurement and model simulation}

\subsection{Measurement sites used for simulation and comparison}

Six measurement sites of $\mathrm{NH}_{3}$ and $p-\mathrm{NH}_{4}^{+}$in Ontario, Canada, were selected as receptors in the model simulations (Fig. 1). Details regarding the six sites can be found in Table 1. The measurements of $\mathrm{NH}_{3}$ were carried out during the Southern Ontario Ammonia Passive Sampler Survey (SOAPSS) (Vet et al., 2008), which ran from 4 April 2006 to 27 March 2007. The objective of the survey was to measure ambient concentrations of $\mathrm{NH}_{3}$ at approximately 78 sites in southern Ontario and a small number of Canadian sites outside of Ontario and US sites in the states along the Great Lakes.
The $\mathrm{NH}_{3}$ measurements represent an integrated average of the $\mathrm{NH}_{3}$ concentration over a one-week (before December, 2006) or two-week (after November, 2006) period at the six selected sites - Longwoods, Egbert, Sprucedale, Chalk River, Haliburton, and St. Mary's - using passive samplers. Of these six sites, $p-\mathrm{NH}_{4}^{+}$concentrations were also measured over 24-h periods by the Canadian Air and Precipitation Monitoring Network (CAPMoN) at four sites - Chalk River, Egbert, Longwoods, and Sprucedale - using a filter-pack system (Sirois, 1997; Zhang et al., 2008). The six sites can be grouped into two categories based on local land use: agriculture and forest (Table 1). These sites were selected mainly to investigate the differences of $\mathrm{NH}_{3}$ and $p-\mathrm{NH}_{4}^{+}$between these two categories in southern Ontario.

\subsection{Simulation setup}

The model was used to simulate $\mathrm{NH}_{3}$ and $p$ - $\mathrm{NH}_{4}^{+}$hourly concentrations at the six sites shown in Fig. 1 for half a year, from 1 June to 30 November 2006. The simulations were driven by meteorological data from the US NCEP's North American Regional Reanalysis (NARR) (Mesinger et al., 2006). The NARR meteorological fields have $349 \times 277$ gridcells with a grid spacing of $32 \mathrm{~km}$ covering all of North America on a Lambert Conformal Conic projection in threehourly intervals. The dataset has 45 vertical layers, including 29 pressure layers from the surface up to $100 \mathrm{hPa}, 5 \mathrm{sub}$ surface layers, and other monolevels. The lowest five pressure layers were set to $1000,975,950,925$, and $900 \mathrm{hPa}$, respectively. Except for cloud levels, incident solar radiation, boundary layer depth, turbulent intensity, cloud bottom/top, which are computed by the STILT-Chem model, all other meteorological variables required by the model are available in 
Table 1. Information regarding the six measurement sites in this study.

\begin{tabular}{lllcc}
\hline Site & Latitude $\left(^{\circ}\right)$ & Longitude $\left(^{\circ}\right)$ & Species measured & Land Use \\
\hline Longwoods & 42.88470 & -81.48056 & $p-\mathrm{NH}_{4}^{+}, \mathrm{NH}_{3}$ & \\
Egbert & 44.23250 & -79.78139 & $p-\mathrm{NH}_{4}^{+}, \mathrm{NH}_{3}$ & Agriculture \\
St. Mary's & 43.218 & -81.142 & $\mathrm{NH}_{3}$ & \\
\hline Sprucedale & 45.42361 & -79.48667 & $p-\mathrm{NH}_{4}^{+}, \mathrm{NH}_{3}$ & \\
Chalk River & 46.06278 & -77.40472 & $p-\mathrm{NH}_{4}^{+}, \mathrm{NH}_{3}$ & Forest \\
Haliburton & 45.1205 & -78.532 & $\mathrm{NH}_{3}$ & \\
\hline
\end{tabular}

NARR. In the simulations, ensembles of 500 particles were released every hour from each site location at a height of $5 \mathrm{~m}$ above ground. The choice of 500 particles will be explained in Sect. 4.1. These particles were run backward in time for six days, which usually allowed them to travel far away from any sources near the receptors. Dynamic integration time steps were used for the back-trajectory calculation. They were computed from the requirement that the advection distance per time-step should be less than the grid spacing (CourantFriedrichs-Lewy condition). The same time steps computed for the back-trajectory transport calculation were also used in the forward simulation for deposition and chemistry calculations. Dry deposition velocities of modeled species were calculated using the Zhang approach.

\subsubsection{Initial/boundary conditions}

Concentrations of modeled species were initialized at the endpoints of trajectories using the output of the Model for OZone And Related chemical Tracers, version 4 (MOZART-4) (Emmons et al., 2010), according to the temporal and spatial locations of trajectory endpoints in the MOZART-4 simulation output. MOZART4 (http://www.acd.ucar.edu/gctm/mozart/models/m4/) is a global chemical transport model which is driven by NCEP/NCAR-reanalysis meteorology and uses emissions based on the Precursors of Ozone and their Effects in the Troposphere (POET) database (Granier et al., 2005), the Regional Emission inventory for Asia (REAS) (Ohara et al., 2007), and the Global Fire Emissions Database version 2 (GFED2) (van der Werf et al., 2006). MOZART-4 output for 2006 was obtained from the WRF-Chem website (http: //www.acd.ucar.edu/wrf-chem/mozart.shtml) for particle initialization in this study. The output has a $2.8^{\circ} \times 2.8^{\circ}$ horizontal resolution with 28 vertical levels from the surface to approximately $2 \mathrm{hPa}$, in a $6-\mathrm{h}$ time interval. Since chemical species in the output of MOZART-4 are different from those of CB4, chemical species in the output were approximately mapped onto CB4 species according to the matching table given by Emmons et al. (2010). After the initialization, the simulation is performed forward in time to simulate the evolution of concentration due to the influences of emissions, chemical reactions and deposition along each trajectory for each time step.

\subsubsection{Emissions datasets and processing}

The Canadian emissions inventory that was used for this study was the 2006 Canadian Criteria Air Contaminants emissions inventory (version 2) from Environment Canada (EC), which incorporates facility-level emissions from the EC National Pollutant Release Inventory plus provincelevel estimates of on-road mobile emissions, off-road mobile emissions, and area emissions (http://www.ec.gc.ca/ inrp-npri/). A special inventory of 2006 Canadian agricultural $\mathrm{NH}_{3}$ emissions that was developed under the Canadian National Agri-Environmental Standards Initiative (NAESI) was also used (Makar et al., 2009). One of the key objectives of NAESI was to improve the 2002 national inventory on $\mathrm{NH}_{3}$ emissions, especially from agricultural sources, using updated, Canadian specific, agricultural activity data and emission factors. The updated inventory can therefore account for spatial variation due to regional differences in farming practices and climatic conditions for each livestock category, and temporal variation due to seasonally different agricultural practices or seasonally variable temperatures that have different effects on agricultural $\mathrm{NH}_{3}$ emissions throughout the year (Ayres et al., 2008). Total Canadian $\mathrm{NH}_{3}$ emission in 2006 is about $5 \mathrm{Mt}$, about $90 \%$ of which are from agricultural. More information about emissions from other source types can be found at http://www.ec.gc. ca/pdb/websol/emissions/2006/2006_canada_e.cfm. The corresponding US and Mexican emissions inventories were the 2005 US National Emissions Inventory (version 4) and the 1999 Mexican emissions inventory. Both were obtained from the US Environmental Protection Agency (http://www.epa. gov/ttn/chief/eiinformation.html). These inventories include emissions for oxides of nitrogen $\left(\mathrm{NO}_{\mathrm{x}}\right), \mathrm{VOC}, \mathrm{NH}_{3}$, carbon monoxide $(\mathrm{CO})$, oxides of sulphur $\left(\mathrm{SO}_{\mathrm{x}}\right)$, and primary particulate matter (PM) with an aerodynamic diameter less than or equal to $10 \mu \mathrm{m}$ and $2.5 \mu \mathrm{m}\left(\mathrm{PM}_{10}\right.$ and $\left.\mathrm{PM}_{2.5}\right)$. More information about these inventories may be found in Pouliot et al. (2012).

The hourly anthropogenic gridded emissions fields used in this study were prepared using the Sparse Matrix Operator 

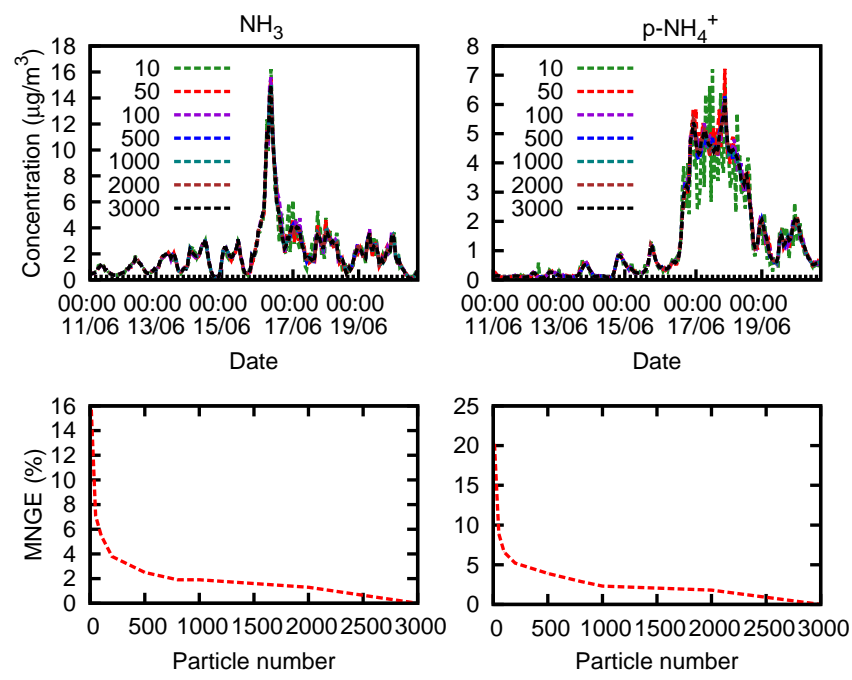

Fig. 2. Sensitivity of the model simulation to the number of particles: modeled $\mathrm{NH}_{3}$ (left) and $p-\mathrm{NH}_{4}^{+}$(right) concentrations (top) at Egbert with different particle numbers; MNGEs (bottom) of $\mathrm{NH}_{3}$ (left) and $p-\mathrm{NH}_{4}^{+}$(right) concentration relative to the simulation with 3000 particles.

Kernel Emission (SMOKE) (v2.4) (UNC, 2009) emissions processing system for a domain (Fig. 1) that consists of $150 \times$ 106 gridcells with a horizontal grid spacing of $42 \mathrm{~km}$ on a secant polar stereographic projection true at $60^{\circ} \mathrm{N}$. Temporal allocations of emissions were performed by SMOKE using predefined temporal profiles, allowing SMOKE-processed emissions to represent diurnal, weekly, and monthly variations. For simplicity all point sources were treated as surface sources, which is reasonable for $\mathrm{NH}_{3}$ emissions. We also incorporated the Models-3 Input/Output Application Programming Interface (IOAPI) (Coats, 2003) into the model to read in emissions fields directly from SMOKE output files.

\section{Results}

\subsection{Sensitivity to particle number}

Due to the stochastic nature of particle (air parcel) trajectories, the accuracy of STILT-Chem is affected by the number of particles used. Theoretically, an infinite number of particles are required to completely represent the ensemble properties of transport to a given measurement location. In reality, however, only a finite number of particles can be simulated due to limited computational resources. This leads to incomplete sampling of trajectory pathways and emissions, resulting in fluctuations in simulated concentrations.

To find the appropriate number of particles in a simulation that can achieve adequate accuracy while also reducing the computational cost, we ran the model with different particle numbers for the Egbert measurement site for ten days. The particle numbers examined included 10, 50, 100, 500, 1000,

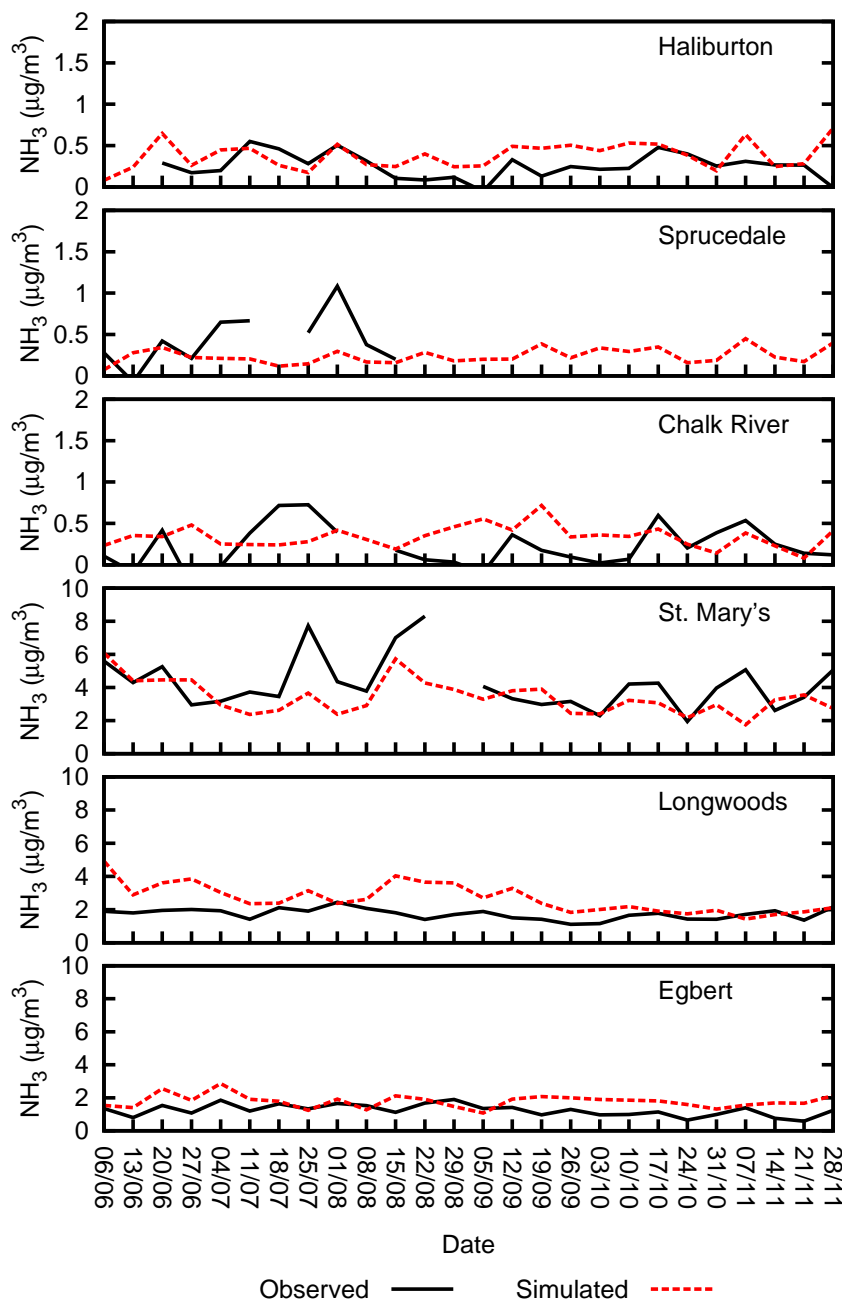

Fig. 3. Modeled (red dash) and measured (black solid) $\mathrm{NH}_{3}$ concentrations $\left(\mu \mathrm{g} \mathrm{m}^{-3}\right)$ for each test site during the simulation period from 1 June to 30 November 2006. Note change in scale between upper and lower panels.

2000 and 3000, and simulated $\mathrm{NH}_{3}$ and $p-\mathrm{NH}_{4}^{+}$concentration time series are presented in Fig. 2. The results show that simulated concentrations with a small particle number are more variable than those with a large number. Discrepancies between simulations with small and large numbers of particles are significant. When the particle number is larger than 500 , however, modeled concentrations converge on the modeled values with 3000 particles and almost overlap with each other. Therefore, we assumed that the modeled results with 3000 particles act like "true values" without error caused by insufficient particles. Figure 2 also shows the deviations of all simulations relative to the simulation with 3000 particles, where the discrepancy is calculated as the Mean Normalized Gross Error (MNGE, defined in Table 2). Since the model run time is proportional to the number of particles, we chose 500 particles for use in the present simulations, which 

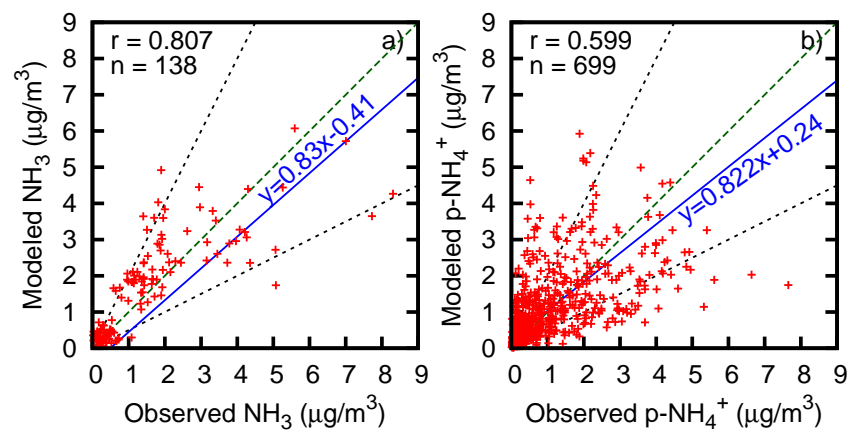

Fig. 4. Correlations between measured and modeled weekly $\mathrm{NH}_{3}$ concentrations $\left(\mu \mathrm{g} \mathrm{m}^{-3}\right)$ for six sites (left) and 24-h $p-\mathrm{NH}_{4}^{+}$(right) concentrations $\left(\mu \mathrm{g} \mathrm{m}^{-3}\right)$ for four sites during the simulation period from 1 June to 30 November 2006. The black dotted lines show agreement within a factor of 2 . Fitted regression (blue solid) lines and $1: 1$ (darkgreen dashed) lines are also plotted.

yielded an MNGE less than $5 \%$ for both $\mathrm{NH}_{3}$ and $p-\mathrm{NH}_{4}^{+}$ compared to a run with 3000 particles.

\subsection{Model performance}

\subsection{1 $\mathrm{NH}_{3}$}

Simulated hourly $\mathrm{NH}_{3}$ concentrations were averaged over each corresponding weekly sampling period and then compared against measurements for all six receptor sites for the simulation period from 1 June to 30 November 2006. The weekly time series shown in Fig. 3 suggest that the model generally performed adequately in predicting the average levels of $\mathrm{NH}_{3}$ observations for most sites, especially for the three sites in forest regions - Sprucedale, Haliburton, and Chalk River. However, the week-to-week variations of the observations were not well captured by the model. The $\mathrm{NH}_{3}$ concentrations at Longwoods, Egbert, Chalk River, and Haliburton were overestimated, whereas those at St. Mary's and Sprucedale were underestimated (see Table 3). The overestimation at Longwoods and underestimation at St. Mary's may indicate that coarse representation (i.e., $42 \mathrm{~km}$ grid spacing) and/or uncertainties in emissions contribute to the underestimation and overestimation of $\mathrm{NH}_{3}$ because emission strengths between those two sites are not significantly different (Fig. 1). There is no indication, on the other hand, of significant overall overestimation or underestimation of $\mathrm{NH}_{3}$ by the model. The better performance of the model for the three sites in the forest region is probably due to the smaller emission fluxes and weaker spatial gradients in their vicinity as compared with the three sites in the agricultural region.

The correlation between measured and modeled concentrations is another frequently used model performance metric. We calculated the correlation between the modeled and measured $\mathrm{NH}_{3}$ concentrations for all test sites and obtained a value of 0.807 (Fig. 4a). Considering the fact that weekly

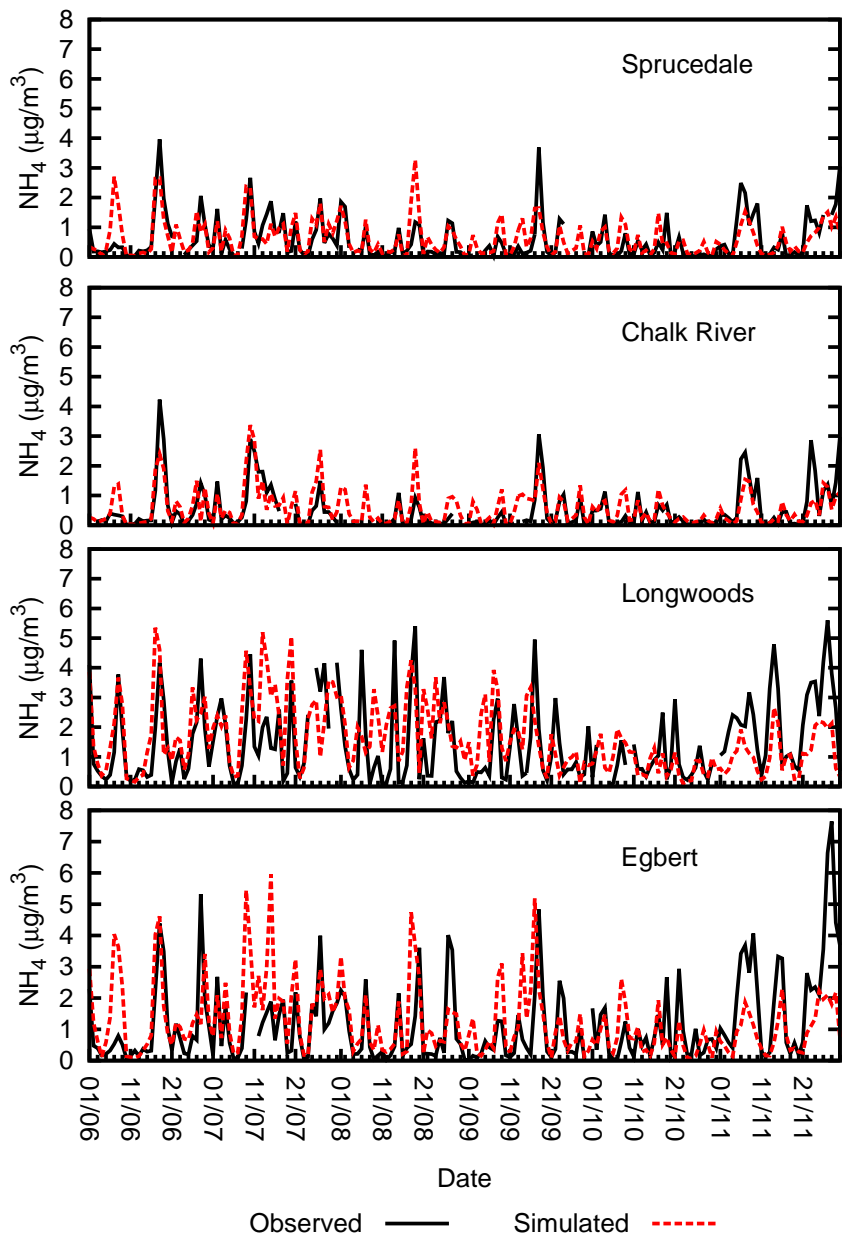

Fig. 5. Modeled (red dash) and measured (black solid) $p-\mathrm{NH}_{4}^{+} 24-$ $\mathrm{h}$ concentrations $\left(\mu \mathrm{g} \mathrm{m}^{-3}\right.$ ) for four test sites during the simulation period from 1 June to 30 November 2006.

$\mathrm{NH}_{3}$ concentrations were used here, this correlation is comparable to those reported in a previous study (Skjøth et al., 2004) using a similar model (ACDEP), in which correlation coefficients for the years 1999-2001 for three sites in Denmark varied from 0.43 to 0.69 when measured and simulated diurnal mean $\mathrm{NH}_{3}$ concentrations were used, and correlation coefficients increased to a range of 0.83 to 0.93 when measured and simulated monthly $\mathrm{NH}_{3}$ concentrations were used. The figure also shows that most calculated concentrations agreed, within a factor of 2 , with observed concentrations. So far, no criteria have been recommended for model performance in $\mathrm{NH}_{3}$ modeling, largely due to the paucity of available $\mathrm{NH}_{3}$ measurement data. In fact, the SOAPSS data of $\mathrm{NH}_{3}$ measurements from a network of sites was the first such dataset available for North America. As a result, we cannot compare model performance for $\mathrm{NH}_{3}$ in this study with results for other models in North America. 
Table 2. Definition of statistical metrics.

\begin{tabular}{lc}
\hline Parameter & Definition \\
\hline Unpaired Peak Accuracy (UPA) & $\left(\frac{P_{\text {peak }}-O_{\text {peak }}}{O_{\text {peak }}}\right) \times 100 \%$ \\
\hline Ratio of the Means (ROM) & $\left(\frac{1}{N} \sum_{i=1}^{N} P_{i}\right) /\left(\frac{1}{N} \sum_{i=1}^{N} O_{i}\right)$ \\
\hline Mean Normalized Gross Error (MNGE) & $\frac{1}{N} \sum_{i=1}^{N}\left|\frac{P_{i}-O_{i}}{O_{i}}\right| \times 100 \%$ \\
\hline Mean Fractional Bias (MFB) & $\frac{1}{N} \sum_{i=1}^{N} \frac{P_{i}-O_{i}}{\left(P_{i}+O_{i}\right) / 2} \times 100 \%$ \\
\hline Mean Fractional Error (MFE) & $\frac{1}{N} \sum_{i=1}^{N} \frac{\left|P_{i}-O_{i}\right|}{\left(P_{i}+O_{i}\right) / 2} \times 100 \%$ \\
\hline
\end{tabular}

$P_{i}$ : prediction at time $i ; O_{i}$ : observation at time $i ; N$ : total number of observations; $P_{\text {peak }}:$ maximum predicted concentration; $O_{\text {peak }}$ : maximum observed concentration.

\subsection{2 $p-\mathrm{NH}_{4}^{+}$}

Hourly simulated $p$ - $\mathrm{NH}_{4}^{+}$concentrations were averaged to daily concentrations to match the CAPMoN filter-pack sampling period. Time series of daily measured and modeled $p$ $\mathrm{NH}_{4}^{+}$concentrations for four of the receptor sites are presented in Fig. 5. Two sites, St. Mary's and Haliburton, were not included due to their lack of $p-\mathrm{NH}_{4}^{+}$measurements. Qualitatively, we can see that the model, in most cases, can simulate the synoptic variations, the timing of the peaks, and the mean levels of the measurements.

Model performance for $p-\mathrm{NH}_{4}^{+}$was also evaluated with measurements for those four sites using two model performance metrics recommended by Boylan and Russell (2006) and US EPA (2007) for aerosols: the mean fractional bias (MFB) and the mean fractional error (MFE), along with the ratio of the means (ROM) and the unpaired peak accuracy (UPA). Their definitions are listed in Table 2. MFB and MFE indicate the overall performance of the model while UPA represents the model's ability to simulate the peak concentrations. As indicated in Table 3, all MFBs and MFEs for $p-\mathrm{NH}_{4}^{+}$meet the acceptable model performance criteria (MFE $\leq 75 \%$ and $-60 \%<$ MFB $<60 \%$ ) suggested by Boylan and Russell (2006). All of the values are also comparable to values reported by other studies (Aksoyoglu et al., 2011; Appel et al., 2008; Tesche et al., 2006), indicating satisfactory performance of the model in simulating $p-\mathrm{NH}_{4}^{+}$. Ratio-of-the-means (ROM) values presented in Table 3 indicate that the model predicted means of $p-\mathrm{NH}_{4}$ measurements very well, with a $2 \%$ to $8 \%$ over-prediction. One of the possible causes of the over-prediction is that the CAPMoN $p-\mathrm{NH}_{4}^{+}$observations measured by a filter-pack system are likely to be lower than actual values because captured $\mathrm{NH}_{4} \mathrm{NO}_{3}$ can be subject to volatility issues (Cheng and Tsai, 1997; Zhang and McMurry, 1987). The statistics in Table 3 also show that there is no significant difference in model performance between sites in agricultural regions (Egbert and Longwoods) and those in forest regions (Sprucedale and Chalk River) for $p-\mathrm{NH}_{4}^{+}$simulations, in part because $p$ $\mathrm{NH}_{4}^{+}$, unlike $\mathrm{NH}_{3}$, is a secondary (regional) pollutant and has smaller spatial gradients.

Lastly, Fig. 4b shows a combined scatterplot of daily $p$ $\mathrm{NH}_{4}^{+}$values for the four receptor sites with measurements. The calculated correlation was 0.599 . This value is comparable with other studies that used forward-in-time Eulerian air quality models, such as a 0.76 correlation obtained for the AURAMS model for a one-year 2002 simulation (Makar et al., 2009) and values ranging from 0.58 to 0.84 obtained by the CMAQ model for different months of 2001 (Appel et al., 2008).

\subsection{Quantitative identification of upstream influences}

\subsubsection{Identification of important upstream locations}

Since the STILT-Chem model simulates an ensemble of air parcel back-trajectories that arrive at the receptor, the evolution of concentrations of modeled species can be calculated along each trajectory for each process involved. This allows us to investigate upstream processes affecting concentrations at specific receptors. Figure 6, for example, shows calculated contributions and losses from different processes in upstream areas. Those values were obtained by averaging within each grid cell the values associated with different trajectories. The different processes either enhanced or reduced the concentration of $\mathrm{NH}_{3}$ in air parcels that arrived at Egbert on 2 July 2006, at 18:00 UTC.

The calculated footprint (Fig. 6a; cf. Sect. 2.2) shows the main air flows that affected the level of $\mathrm{NH}_{3}$ simulated at Egbert at that time. Figure $6 \mathrm{~b}$ shows the net emission 
Table 3. Statistic for predicted $\mathrm{NH}_{3}$ and $p-\mathrm{NH}_{4}^{+}$concentrations.

\begin{tabular}{|c|c|c|c|c|c|c|c|c|}
\hline \multirow{2}{*}{ Site } & \multicolumn{2}{|c|}{ UPA(\%) } & \multicolumn{2}{|c|}{ ROM } & \multicolumn{2}{|c|}{$\operatorname{MFB}(\%)$} & \multicolumn{2}{|c|}{$\operatorname{MFE}(\%)$} \\
\hline & $\mathrm{NH}_{3}$ & $p-\mathrm{NH}_{4}^{+}$ & $\mathrm{NH}_{3}$ & $p-\mathrm{NH}_{4}^{+}$ & $\mathrm{NH}_{3}$ & $p-\mathrm{NH}_{4}^{+}$ & $\mathrm{NH}_{3}$ & $p-\mathrm{NH}_{4}^{+}$ \\
\hline Longwoods & 101.3 & -6.5 & 1.54 & 1.06 & 38.8 & 16.4 & 41.7 & 66.9 \\
\hline Egbert & 50.3 & -22.5 & 1.43 & 1.04 & 36.2 & 19.9 & 41.9 & 69.0 \\
\hline St. Mary's & -26.9 & & 0.80 & & -20.2 & & 30.6 & \\
\hline Sprucedale & -58.9 & -19.2 & 0.55 & 1.02 & -31.9 & 22.1 & 94.7 & 60.9 \\
\hline Chalk River & 6.6 & -21.1 & 1.59 & 1.08 & 85.5 & 32.9 & 122.3 & 60.5 \\
\hline Haliburton & 27.3 & & 1.51 & & 55.8 & & 69.9 & \\
\hline
\end{tabular}
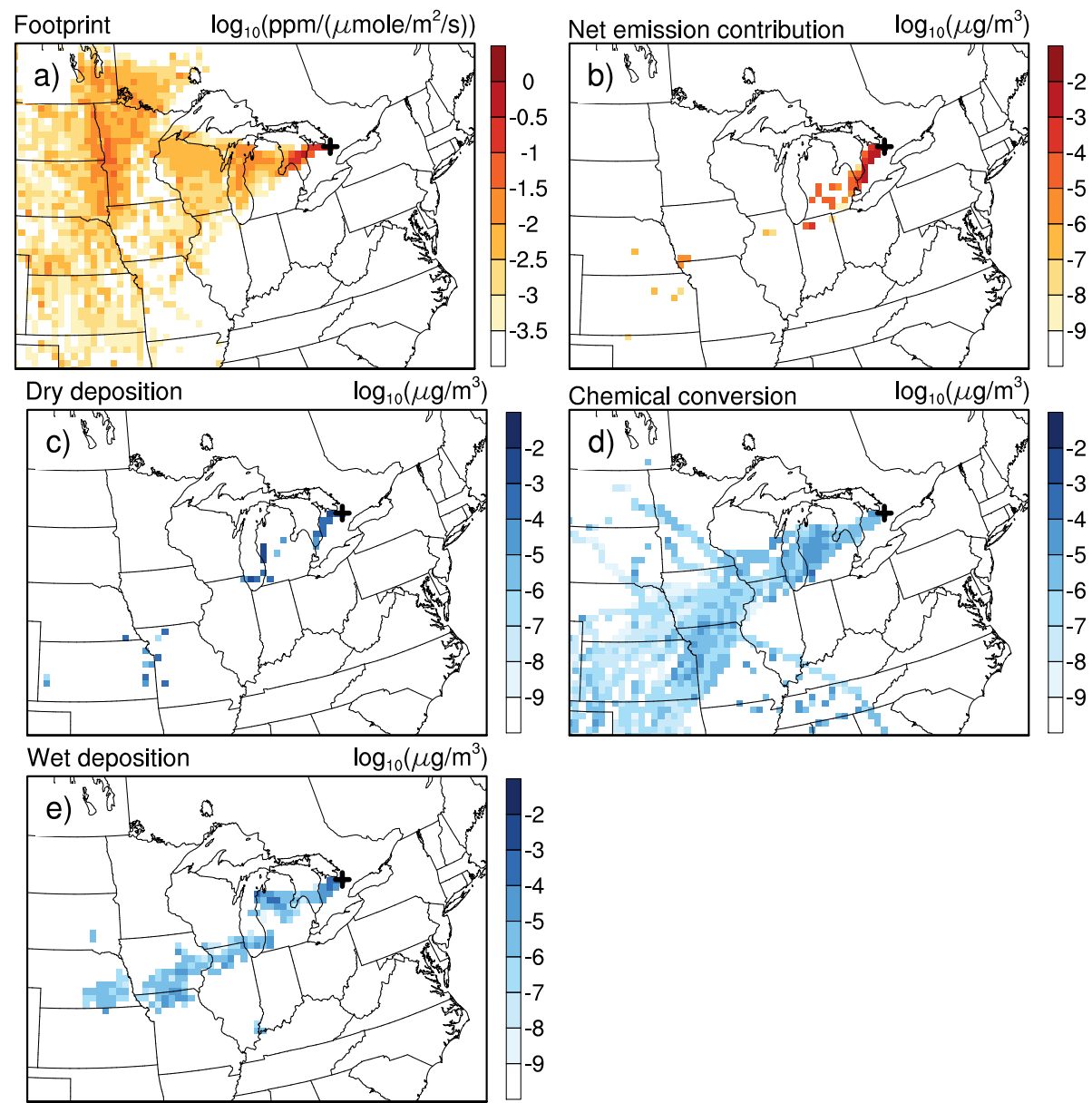

Fig. 6. Modeled upstream parameters and processes impacting $\mathrm{NH}_{3}$ concentration simulated at Egbert (location indicated by "+") at 18:00 UTC on 2 July 2006, including: (a) footprint (i.e., the sensitivity of modeled $\mathrm{NH}_{3}$ concentration at Egbert at that time to each upstream location); (b) net emission contribution (red color scale); (c) loss (blue scale) due to dry deposition; (d) loss due to chemical conversion; and (e) loss due to wet deposition.

contribution of every upstream location to the $\mathrm{NH}_{3}$ concentration at the receptor on 2 July 2006, at 18:00 UTC. The value in each gridcell represents the net amount of $\mathrm{NH}_{3}$ emitted from that gridcell that "makes it" to the receptor at the specific time, while accounting for removal from loss processes. Losses of $\mathrm{NH}_{3}$ arriving at the receptor due to dry removal, chemical conversion, and wet removal in each upstream location are presented in Fig. 6c, d and e, respectively. The $\mathrm{NH}_{3}$ concentration was mainly enhanced by local sources. Only dry deposition in a small part of upstream locations significantly reduced the $\mathrm{NH}_{3}$ concentration because dry deposition can only take place within the surface layer. 

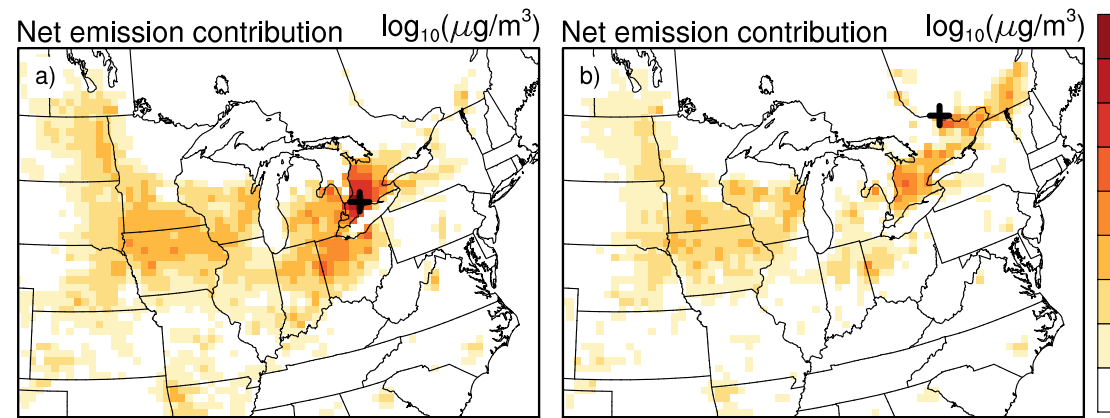

$-1$

$-1.5$

$-2$

$-2.5$

$-3$

$-3.5$

$-4$
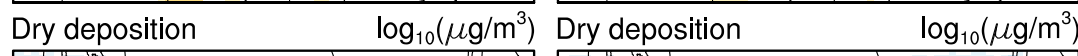

$-4.5$
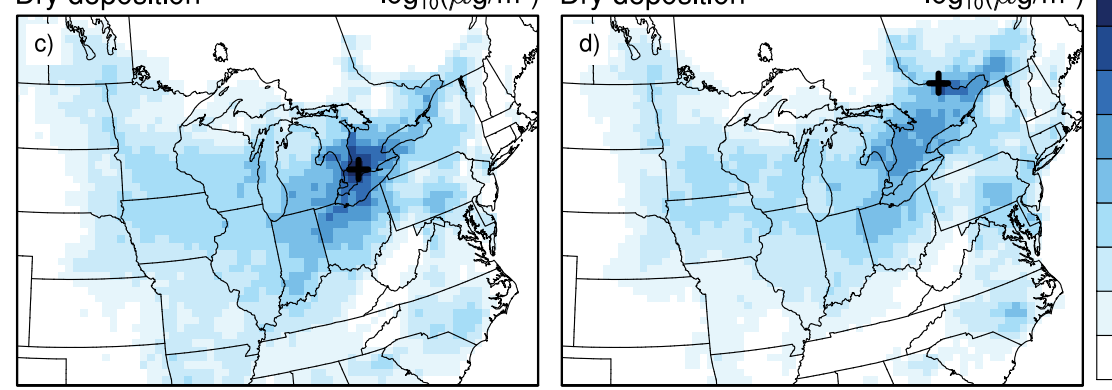

$-1$

$-1.5$

$-2$

$-2.5$

$-3$

$-3.5$

$-4$

$-4.5$

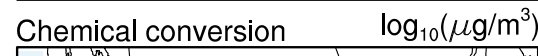

Chemical conversion
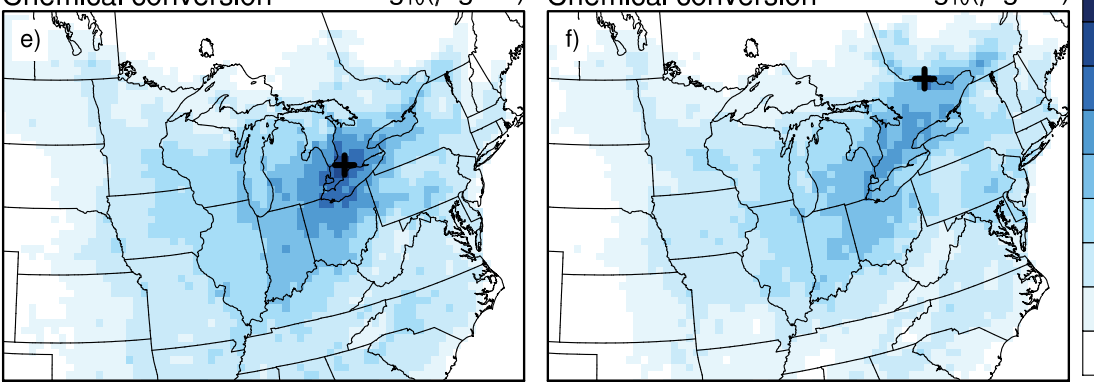

$-1$

$-1.5$

$-2$

$-2.5$

$-3$

$-3.5$

$-4$

$-4.5$
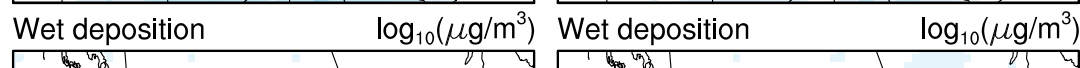

$-1$
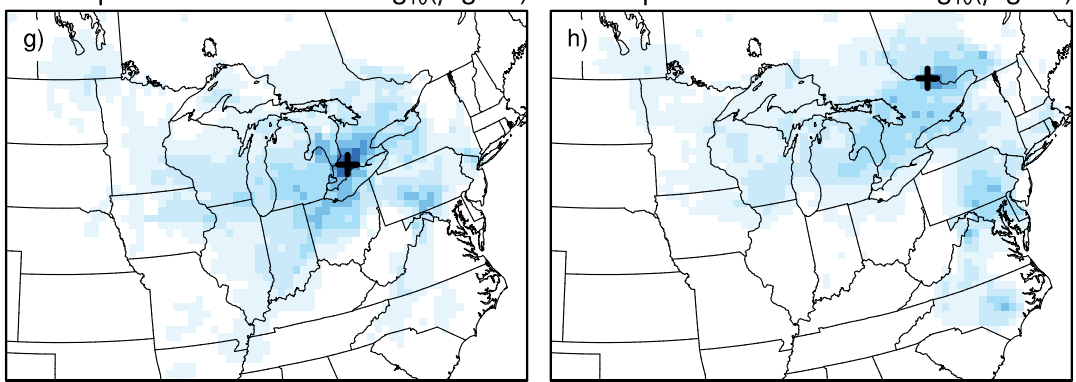

$-1.5$

$-2$

$-2.5$

$-3$

$-3.5$

$-4$

$-4.5$

Fig. 7. Modeled upstream influences on simulated $\mathrm{NH}_{3}$ concentrations from net emission contribution (a and b); dry deposition (c and d); chemical conversion (e and f); and wet deposition ( $\mathbf{g}$ and $\mathbf{h}$ ) over 6 months at two sites: Longwoods (left) and Chalk River (right). Each panel shows an average over the entire simulation period. Red color scale represents positive contributions (source) whereas blue scale represents negative contributions (loss). Site locations are indicated by "+".

Compared against dry deposition, loss from chemical conversion took place over a more widespread upstream region due to the fact that chemical conversion can take place at higher altitudes rather than being restricted to the surface layer. Loss of $\mathrm{NH}_{3}$ from wet removal is highly localized and dependent on precipitation rates in the upstream regions.

The results presented in Fig. 6 are only useful for investigating upstream sources or sinks influencing the receptor at one time. However, the same analyses can be averaged over a long time period to identify upstream sources and sinks that impact receptors significantly. As an example, the upstream contributions and losses caused by different processes as shown in Fig. 6 such as emissions, dry deposition, wet deposition and chemical conversion were tallied for each simulation hour, and were then averaged over the entire six-month simulation period. The resulting averages are displayed in 


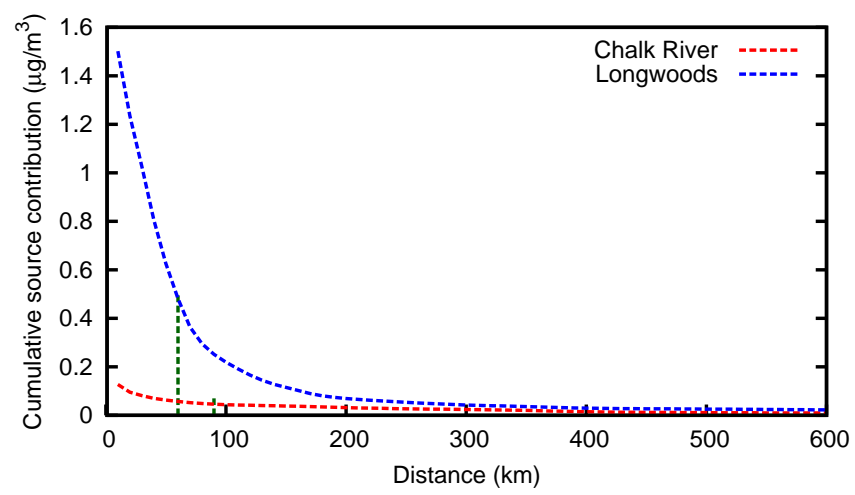

Fig. 8. Simulated cumulative net source contribution of $\mathrm{NH}_{3}$ as a function of the distances of source areas to Longwoods (blue dashed line) and Chalk River (red dashed line) over the entire simulation period. Green dashed lines show the distances at which cumulative contribution declined to 1/e of the final accumulated source contribution within $10 \mathrm{~km}$ of the receptor.

Fig. 7 for two sites, Longwoods and Chalk River, with very different characteristics (Fig. 1).

Figure 7 clearly shows that, averaged over 6 months, $\mathrm{NH}_{3}$ concentrations at receptors were mainly influenced by air flows from west and southwest. Sources and atmospheric processes in western and southwestern regions to the receptors greatly affected them. $\mathrm{NH}_{3}$ concentrations at receptors were enhanced (represented in red color) by emissions from the upstream areas. Net source contributions from different upstream locations also differ significantly. The main source regions that impact Longwoods and Chalk River are located in southwestern Ontario in Canada, Iowa, Minnesota, Wisconsin, Michigan, Indiana, and the northern part of Ohio, in the US. As noted earlier, Longwoods is representative of sites associated with extensive local agricultural operations and near strong $\mathrm{NH}_{3}$ sources while Chalk River is a forested site surrounded by low emission strengths. The strengths of the net emission contributions of these areas to Longwoods were much higher than to Chalk River. Dry deposition and chemical transformation are the major depletion processes (represented in blue color) of $\mathrm{NH}_{3}$ in the upstream areas while wet deposition is less important. Southwestern Ontario, Michigan, and northern Ohio were identified as important upstream areas for the loss of $\mathrm{NH}_{3}$ concentrations due to dry deposition process. Chemical conversion in Southwestern Ontario, Michigan, Ohio and Wisconsin was important for two receptors. The influence of wet deposition is mainly dependent on the precipitation amount and $\mathrm{NH}_{3}$ concentrations in the upstream areas. Wet deposition in southwestern Ontario, Michigan, Pennsylvania and areas in the vicinity of the two sites affected $\mathrm{NH}_{3}$ at both sites; however, its influence is the smallest mainly because of the sporadic nature of precipitation.

In order to illustrate the relationship between net source contribution strengths and distances to a receptor, we calculated net source contribution accumulations as a function

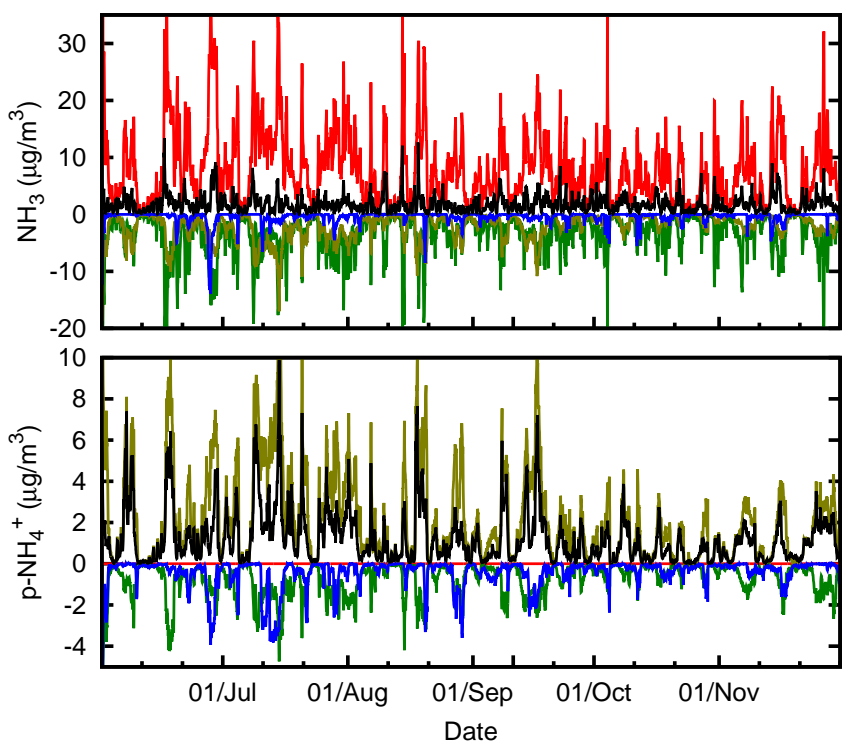

$\begin{array}{lll}\text { Simulated concentration } & - & \text { Dry deposition } \\ \text { Emission } & \quad \text { Wet deposition }\end{array}$

Fig. 9. Simulated $\mathrm{NH}_{3}$ (top) and $p-\mathrm{NH}_{4}^{+}$(bottom) concentrations (black) at Egbert, compared against modeled contributions or losses from emission (red), dry deposition (green), wet deposition (blue), and chemical conversion (olive) for the entire simulation period.

of distance to the receptors for the entire simulation period. The time-averaged contribution accumulations were shown in Fig. 8 as functions of distances to two sites - Longwoods and Chalk River. Clearly, strengths of net source contributions to $\mathrm{NH}_{3}$ concentrations greatly depend on their distances to the sites. The cumulative net source contributions declined nearly exponentially with distances away from a receptor. E-folding distances for the two sites were also presented in Fig. 8 (green dashed lines) to show the distances at which source contribution accumulations declined to $1 / e$ of the accumulation averages within $10 \mathrm{~km}$. The e-folding distance was about $90 \mathrm{~km}$ for Chalk River, approximately 1.5 times longer than that (about $60 \mathrm{~km}$ ) for Longwoods, indicating that $\mathrm{NH}_{3}$ concentrations at Longwoods were mainly contributed by strong local sources.

\subsubsection{Analysis of contributions of upstream processes}

Key atmospheric processes such as turbulent diffusion, deposition, and chemical conversion depend on meteorological conditions such as wind direction, wind speed, temperature, and precipitation. Thus, these processes may vary in upstream areas at different times, dynamically affecting the concentrations of a species at a receptor. In order to understand the relative importance of each process, total upstream influences of each process on the simulated $\mathrm{NH}_{3}$ and $p-\mathrm{NH}_{4}^{+}$ concentrations at the Egbert site were calculated for each simulation hour. 
Table 4. Ratios of each sink term, and total sinks to total sources for $\mathrm{NH}_{3}$ and $p-\mathrm{NH}_{4}^{+}$.

\begin{tabular}{|c|c|c|c|c|c|c|c|c|}
\hline \multirow{2}{*}{ Type } & \multirow{2}{*}{ Site } & \multicolumn{4}{|c|}{$\mathrm{NH}_{3}$} & \multicolumn{3}{|c|}{$p-\mathrm{NH}_{4}^{+}$} \\
\hline & & TSK/TSC & $\mathrm{D} / \mathrm{TSC}$ & W/TSC & $\mathrm{C} / \mathrm{TSC}$ & TSK/TSC & $\mathrm{D} / \mathrm{TSC}$ & W/TSC \\
\hline \multirow{3}{*}{ Agriculture } & Longwoods & 0.69 & 0.37 & 0.05 & 0.27 & 0.45 & 0.28 & 0.17 \\
\hline & Egbert & 0.78 & 0.45 & 0.06 & 0.27 & 0.57 & 0.37 & 0.20 \\
\hline & St. Mary's & 0.68 & 0.40 & 0.05 & 0.23 & 0.49 & 0.32 & 0.17 \\
\hline \multirow{3}{*}{ Forest } & Sprucedale & 0.94 & 0.47 & 0.08 & 0.39 & 0.76 & 0.47 & 0.29 \\
\hline & Chalk River & 0.90 & 0.43 & 0.09 & 0.39 & 0.78 & 0.45 & 0.33 \\
\hline & Haliburton & 0.91 & 0.47 & 0.07 & 0.38 & 0.72 & 0.47 & 0.25 \\
\hline
\end{tabular}

TSK: total sinks. TSC: total sources. D: Dry deposition. W: Wet deposition. C: Chemical conversion. C/TSC $=1.0$ for $p-\mathrm{NH}_{4}^{+}$because chemical conversion is the only source.
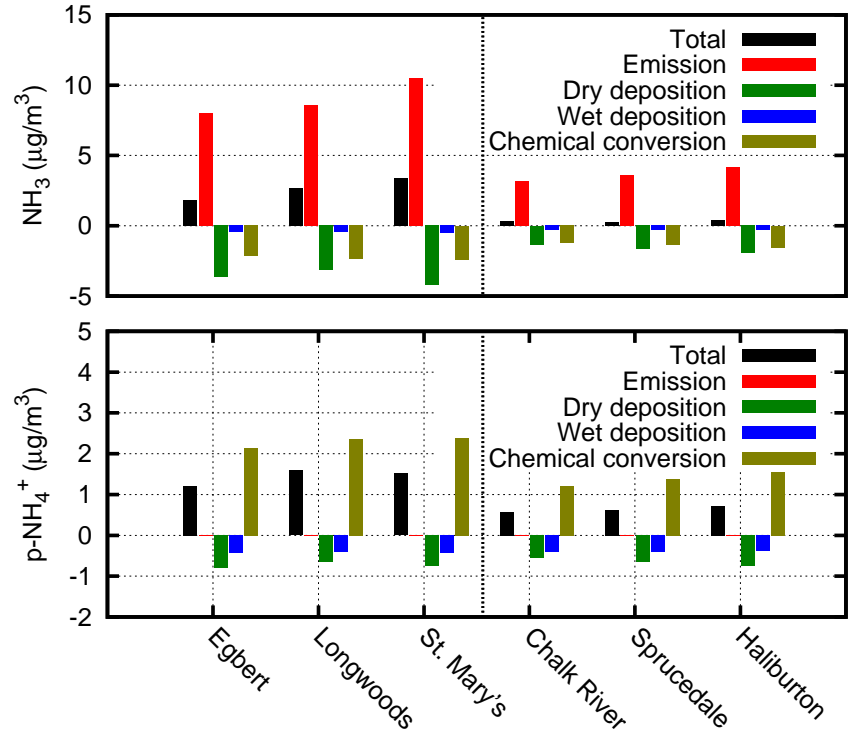

Fig. 10. Mean contributions to $\mathrm{NH}_{3}$ (top) and $p-\mathrm{NH}_{4}^{+}$(bottom) due to emissions (red), or losses due to dry deposition (green), wet deposition (blue), and chemical conversion (olive). The total enhancement over the background is shown in black. These mean contributions were obtained by averaging each contribution over the entire six-month simulation period.

The time series of different upstream processes are presented in Fig. 9, along with the simulated $\mathrm{NH}_{3}$ and $p-\mathrm{NH}_{4}^{+}$ concentrations (the net contribution of all those processes) for the purpose of comparison. Note that negative values here refer to loss whereas positive values denote enhancement, and emission contribution here refers to gross contribution (excluding the impact of any loss process). We can see that the simulated concentrations and influences from each process vary considerably with simulation time, due to changing upstream areas and different behaviors of atmospheric processes in those areas. With the exception of emissions, all other processes reduced $\mathrm{NH}_{3}$ concentrations. Gross emission contributions to $\mathrm{NH}_{3}$ at Egbert vary from 0 to more than $30 \mu \mathrm{g} \mathrm{m}^{-3}$, with an average of $8 \mu \mathrm{g} \mathrm{m}^{-3}$. The time series for dry deposition, another surface process, varies in almost the same pattern as from emission contributions. However, dry deposition losses are smaller in absolute magnitude, varying from -20 to $0 \mu \mathrm{g} \mathrm{m}^{-3}$ with an average around $-4 \mu \mathrm{g} \mathrm{m}^{-3}$, which are greater than losses from chemical conversion that vary between -15 to $0 \mu \mathrm{g} \mathrm{m}^{-3}$ with an average of $-2 \mu \mathrm{g} \mathrm{m}^{-3}$. Losses from wet deposition depend on the amount of precipitation and are generally the smallest, with an average less than $-1 \mu \mathrm{g} \mathrm{m}^{-3}$.

Unlike $\mathrm{NH}_{3}$, the sole contributor to $p-\mathrm{NH}_{4}^{+}$is chemical conversion, with an average around $2 \mu \mathrm{g} \mathrm{m}^{-3} \cdot p-\mathrm{NH}_{4}^{+}$losses from both dry deposition and wet deposition are approximately within a range from -4 to $0 \mu \mathrm{g} \mathrm{m}^{-3}$; however, the average loss from wet deposition is around $-0.4 \mu \mathrm{g} \mathrm{m}^{-3}$, about half of the average loss from dry deposition.

Figure 10 shows the average contribution or loss from each process over the entire simulation period at all six sites, derived from time averaging the time series of different process contributions or losses (an example of such time series is Fig. 9 for Egbert). We can see that dry deposition and chemical conversion are the dominant processes in loss of $\mathrm{NH}_{3}$, whereas $p-\mathrm{NH}_{4}^{+}$is depleted by both dry and wet deposition. Wet deposition plays a more significant role in loss of $p$ $\mathrm{NH}_{4}^{+}$than $\mathrm{NH}_{3}$. The simulation results indicate that the level of $\mathrm{NH}_{3}$ could be more than two times higher than the values seen in Fig. 3 if removal processes were absent.

The differences of upstream process contributions or losses to $\mathrm{NH}_{3}$ are significant between the agricultural sites (Egbert, Longwoods, and St. Mary's) and the forest sites (Chalk River, Sprucedale, and Haliburton). On average, gross emission contribution, dry removal, wet removal, and chemical conversion to the agricultural sites are 2.5, 2.2, 1.6 and 1.7 times the values to forest sites, respectively. For $p-\mathrm{NH}_{4}^{+}$, as a secondary pollutant with weaker spatial variability and a longer atmospheric lifetime, results indicate much smaller difference between the two groups of sites. Dry deposition, wet deposition and chemical conversion to the agricultural 
sites are 1.3, 1.1 and 1.7 times the values to forest sites, respectively.

We calculated the ratio of each sink (loss) to total sources (gross contribution) for each site using results displayed in Fig. 10, and the resulting values are shown in Table 4. Ratios of total sinks to total sources are calculated as well. Between the two groups of sites, the difference in ratios of total sinks to total sources is significant. The forest sites are on average 0.20 and 0.22 larger than the agricultural sites for $\mathrm{NH}_{3}$ and $p-\mathrm{NH}_{4}^{+}$, respectively. Out of the 0.20 , the difference for $\mathrm{NH}_{3}$, $65 \%$ is attributed to the difference $(0.13)$ in ratios of chemical conversion to total sources. We suspect that such a large difference resulted from significant difference in air temperatures due to different latitudes of the two groups sites: estimated from NARR dataset of the first layer (975-1000 mb), air temperature mean over the entire simulation period for the forest sites is about $2^{\circ} \mathrm{C}$ lower than for the agriculture sites. In the chemical processes of $\mathrm{NH}_{3}$, the $\mathrm{NH}_{3} / \mathrm{HNO}_{3} / \mathrm{NH}_{4} \mathrm{NO}_{3}$ equilibrium is very sensitive to the temperature (Stelson et al., 1979; Seinfeld and Pandis, 2006). An increase in temperature from $20^{\circ} \mathrm{C}$ to $30^{\circ} \mathrm{C}$ could increase the equilibrium gas-phase concentration of $\mathrm{NH}_{3}$ and $\mathrm{HNO}_{3}$ (equimolar) from 11.0 to $38.4 \mu_{\mathrm{g} \mathrm{m}^{-3}}$ (Stelson et al., 1979), indicating a significant reduction in gas-to-aerosol chemical conversion of $\mathrm{NH}_{3}$. For $p-\mathrm{NH}_{4}^{+}$, the largest contributor to the difference in ratios of total sinks to total sources between the two groups of sites is dry deposition, accounting for about $64 \%(0.14)$ of total difference (0.22), mainly because the dry deposition velocities of $p-\mathrm{NH}_{4}^{+}$are generally larger for forest surface than crop surface (Zhang et al., 2001).

\section{Conclusion and discussion}

The STILT-Chem model was improved in this study by incorporating a new chemistry module to simulate atmospheric $\mathrm{NH}_{3}$ and $p-\mathrm{NH}_{4}^{+}$. Thus, the improved model can be utilized to simulate transport, emission, deposition and chemical transformation for gas-phase species, as well as multiphase species involved in the key atmospheric reactions of $\mathrm{NH}_{3}$ and $p-\mathrm{NH}_{4}^{+}$. The model was applied to six measurement sites in Ontario, Canada. Simulated results were evaluated against a unique set of measurements for a six-month period in 2006. The comparison demonstrated satisfactory performance of the model for $p$ - $\mathrm{NH}_{4}^{+}$. Relatively poor performance for $\mathrm{NH}_{3}$ is likely due to the strong spatial variability of $\mathrm{NH}_{3}$ and uncertainties in the $\mathrm{NH}_{3}$ emissions and/or their coarse-scale grid spacing.

The model can also be applied as an effective tool to quantitatively investigate and understand upstream sources, sinks, and atmospheric processes that significantly and frequently affect concentrations at selected receptors since it is a backtrajectory-based model, and the influence of each major process on the simulated or observed concentration at receptors can be calculated for every upstream location at each time step. This kind of application has been demonstrated in the study. The modeled results suggest that the concentrations of $\mathrm{NH}_{3}$ at those sites were most significantly affected by sources and processes in Michigan, Wisconsin, Ohio, southwestern Ontario and nearby areas. Dry deposition is the major removal process for both $\mathrm{NH}_{3}$ and $p-\mathrm{NH}_{4}^{+}$in the atmosphere during the study period.

This study also revealed the contrast between agricultural versus forest sites. Not only were emissions of $\mathrm{NH}_{3}$ higher in agricultural areas, but removal mechanisms (especially chemical loss for $\mathrm{NH}_{3}$ and dry deposition for $p$ - $\mathrm{NH}_{4}^{+}$) were more efficient in forests. This combination explains the significantly higher concentrations of $\mathrm{NH}_{3}$ and $p-\mathrm{NH}_{4}^{+}$observed at agricultural sites.

Although the improved STILT-Chem can reasonably simulate atmospheric $\mathrm{NH}_{3}$ and $p-\mathrm{NH}_{4}^{+}$, the treatment of multiphase reactions is highly simplified. Only the dominant multi-phase reactions involving ammonia and ammonium were considered in the model. Further development of the model will focus on incorporating major atmospheric aqueous and aerosol chemistry, and a dry deposition scheme that accounts for bi-directional exchange of ammonia.

Acknowledgements. We gratefully acknowledge funding from Environment Canada for supporting D. Wen and for the Canadian Air and Precipitation Monitoring Network data. We thank Q. Zheng and J. Zhang of Environment Canada for preparing the emissions files used in this study. This work was made possible by the facilities of the Shared Hierarchical Academic Research Computing Network (SHARCNET: www.sharcnet.ca) and Compute/Calcul Canada.

Edited by: V. Grewe

\section{References}

Aksoyoglu, S., Keller, J., Barmpadimos, I., Oderbolz, D., Lanz, V. A., Prévôt, A. S. H., and Baltensperger, U.: Aerosol modelling in Europe with a focus on Switzerland during summer and winter episodes, Atmos. Chem. Phys., 11, 7355-7373, doi:10.5194/acp11-7355-2011, 2011.

Alexander, B., Park, R. J., Jacob, D. J., Li, Q. B., Yantosca, R. M., Savarino, J., Lee, C. C. W., and Thiemens, M. H.: Sulfate formation in sea-salt aerosols: Constraints from oxygen isotopes, J. Geophys. Res., 110, D10307, doi:10.1029/2004JD005659, 2005.

Appel, K. W., Bhave, P. V., Gilliland, A. B., Sarwar, G., and Roselle, S. J.: Evaluation of the Community Multiscale Air Quality (CMAQ) model version 4.5: Sensitivities impacting model performance; Part II - particulate matter, Atmos. Environ., 42, 6057-6066, 2008.

ApSimon, H. M., Barker, B. M., and Kayin, S.: Modelling studies of the atmospheric release and transport of ammonia in anticyclonic episodes, Atmos. Environ., 28, 665-678, doi:10.1016/13522310(94)90043-4, 1994. 
Asman, W. A. H.: Modelling the atmospheric transport and deposition of ammonia and ammonium: an overview with special reference to Denmark, Atmos. Environ., 35, 1969-1983, doi:10.1016/S1352-2310(00)00548-3, 2001.

Asman, W. A. H. and van Jaarsveld, J. A.: A variable-resolution transport model applied for $\mathrm{NH}_{\mathrm{X}}$ in Europe, Atmos. Environ., 26A, 445-464, doi:10.1016/0960-1686(92)90329-J, 1992.

Asman, W. A. H., Sutton, M. A., and Schjørring, J. A. N. K.: Ammonia: emission, atmospheric transport and deposition, New Phytologist, 139, 27-48, doi:10.1046/j.14698137.1998.00180.x, 1998.

Ayres, J., Bittman, S., Sheppard, S., and Girdhar, S.: Sources of ammonia emissions, in: Canadian Atmospheric Assessment of Agricultural Ammonia, edited by: Lillyman, C. and Buset, K., 112-130. National Agri-Environmental Standards Technical Series Report No. 4-1, 2008.

Berge, H.: New temporal variation of ammonia emissions, in Benedictow et al.: Transboundary acidification, eutrophication and ground level ozone in Europe in 2008, Joint MSC-W \& CCC \& CEIP Report, Norwegian Meteorological Institute, 2010.

Boylan, J. W. and Russell, A. G.: PM and light extinction model performance metrics, goals, and criteria for three-dimensional air quality models, Atmos. Environ., 40, 4946-4959, 2006.

Brandt, J., Silver, J. D., Frohn, L. M., Geels, C., Gross, A., Hansen, A. B., Hansen, K. M., Hedegaard, G. B., Skjøth, C. A., Villadsen, H., Zare, A., and Christensen, J. H.: An integrated model study for Europe and North America using the Danish Eulerian Hemispheric Model with focus on intercontinental transport of air pollution, Atmos. Environ., 53, 156-176, doi:10.1016/j.atmosenv.2012.01.011, 2012.

Charlson, R. J. and Rodhe, H.: Factors controlling the acidity of natural rainwater, Nature, 295, 683-685, 1982.

Cheng, Y. H. and Tsai, C. J.: Evaporation loss of ammonium nitrate particles during filter sampling, J. Aerosol Sci., 28, 1553-1567, 1997.

Coats, C.: The EDSS/Models-3 I/O API: User Manual, Baron Advanced Meteorological Systems, available at: http://www. baronams.com/products/ioapi (last access: 30 June 2012), 2003.

de Leeuw, G., Skjøth, C. A., Hertel, O., Jickells, T., Spokes, L., Vignati, E., Frohn, L., Frydendall, J., Schulz, M., Tamm, S., Sørensen, L. L., and Kunz, G. J.: Deposition of nitrogen into the North Sea, Atmos. Environ., 37, Supplement 1, 145-165, doi:10.1016/S1352-2310(03)00246-2, 2003.

Draxler, R. R. and Hess, G. D.: Description of the HYSPLIT 4 modeling system, NOAA Technical Memorandum ERL ARL-224, 1997.

EMEP: Transboundary photooxidant air pollution in Europe. Calculations of tropospheric ozone and comparison with observations, EMEP/MSC-W Report 2/98, Oslo, Norway, 1998.

Emmons, L. K., Walters, S., Hess, P. G., Lamarque, J.-F., Pfister, G. G., Fillmore, D., Granier, C., Guenther, A., Kinnison, D., Laepple, T., Orlando, J., Tie, X., Tyndall, G., Wiedinmyer, C., Baughcum, S. L., and Kloster, S.: Description and evaluation of the Model for Ozone and Related chemical Tracers, version 4 (MOZART-4), Geosci. Model Dev., 3, 43-67, doi:10.5194/gmd3-43-2010, 2010.

Gear, C. W.: Numerical Initial Value Problems in Ordinary Differential Equations, Prentice-Hall, Englewood Cliffs, NJ, 1971.
Gery, M. W., Whitten, G. Z., Killus, J. P., and Dodge, M. C.: A photochemical kinetics mechanism for urban and regional scale computer modeling, J. Geophys. Res., 94, 12925-12956, 1989.

Granier, C., Guenther, A., Lamarque, J., Mieville, A., Muller, J., Olivier, J., Orlando, J., Peters, J., Petron, G., Tyndall, G., and Wallens, S.: POET, a database of surface emissions of ozone precursors, available at: http://www.aero.jussieu.fr/projet/ ACCENT/POET.php (last access: 30 June 2012), 2005.

Gyldenkœrne, S., Ambelas Skjøth, C., Hertel, O., and Ellermann, T.: A dynamical ammonia emission parameterization for use in air pollution models, J. Geophys. Res., 110, D07108, doi:10.1029/2004JD005459, 2005.

Hanna, S. R.: Applications in air pollution modeling, in: Atmospheric Turbulence and Air Pollution Modeling, edited by: Nieuwstadt, F. T. M. and van Dop, H., D. Reidel, Norwell, Mass., 358 pp., 1982.

Hertel, O., Christensen, J., Runge, E. H., Asman, W. A. H., Berkowicz, R., Hovmand, M. F., and Hov, O.: Development and Testing of A New Variable Scale Air-Pollution Model - ACDEP, Atmos. Environ., 29, 1267-1290, doi:10.1016/1352-2310(95)00067-9, 1995.

Hertel, O., Skjøth, C. A., Frohn, L. M., Vignati, E., Frydendall, J., de Leeuw, G., Schwarz, U., and Reis, S.: Assessment of the atmospheric nitrogen and sulphur inputs into the North Sea using a Lagrangian model, Phys. Chem. Earth, 27, 1507-1515, doi:10.1016/S1474-7065(02)00153-5, 2002.

Hertel, O., Skjøth, C. A., Brandt, J., Christensen, J. H., Frohn, L. M., and Frydendall, J.: Operational mapping of atmospheric nitrogen deposition to the Baltic Sea, Atmos. Chem. Phys., 3, 2083-2099, doi:10.5194/acp-3-2083-2003, 2003.

Hicks, B. B.: A climatology of wet deposition scavenging ratios for the United States, Atmos. Environ., 39, 1585-1596, 2005.

Hoffmann, M. R. and Calvert, J. G.: Chemical transformation modules for Eulerian acid deposition models: Vol. II. The aqueousphase chemistry, Acid Deposition Modeling Project, National Center for Atmospheric Research, 1985.

Kryza, M., Dore, A. J., Blas, M., and Sobik, M.: Modelling deposition and air concentration of reduced nitrogen in Poland and sensitivity to variability in annual meteorology, J. Environ. Manage., 92, 1225-1236, doi:10.1016/j.jenvman.2010.12.008, 2011.

Lin, J. C., Gerbig, C., Wofsy, S. C., Andrews, A. E., Daube, B. C., Davis, K. J., and Grainger, C. A.: A near-field tool for simulating the upstream influence of atmospheric observations: The Stochastic Time-inverted Lagrangian Transport (STILT) Model, J. Geophys. Res., 108, 4493, doi:10.1029/2002JD003161, 2003.

Makar, P. A., Moran, M. D., Zheng, Q., Cousineau, S., Sassi, M., Duhamel, A., Besner, M., Davignon, D., Crevier, L.-P., and Bouchet, V. S.: Modelling the impacts of ammonia emissions reductions on North American air quality, Atmos. Chem. Phys., 9, 7183-7212, doi:10.5194/acp-9-7183-2009, 2009.

Mesinger, F., DiMego, G., Kalnay, E., Mitchell, K., Shafran, P. C., Ebisuzaki, W., Jovi, D., Woollen, J., Rogers, E., Berbery, E. H., Ek, M. B., Fan, Y., Grumbine, R., Higgins, W., Li, H., Lin, Y., Manikin, G., Parrish, D., and Shi, W.: North American regional reanalysis, B. Am. Meteorol. Soc., 97, 343-360, 2006.

Morris, J. T.: Effects of nitrogen loading on wetland ecosystems with particular reference to atmospheric deposition, Ann. Rev. Ecol. Syst., 22, 257-279, 1991. 
Mozurkewich, M.: The dissociation constant of ammonium nitrate and its dependence on temperature, relative humidity, and particle size, Atmos. Environ., 27, 261-270, 1993.

Nenes, A., Pandis, S. N., and Pilinis, C.: Continued development and testing of a new thermodynamic aerosol module for urban and regional air quality models, Atmos. Environ., 33, 15531560, 1999.

Nopmongcol, U., Koo, B., Tai, E., Jung, J., Piyachaturawat, P., Emery, C., Yarwood, G., Pirovano, G., Mitsakou, C., and Kallos, G.: Modeling Europe with CAMx for the Air Quality Model Evaluation International Initiative (AQMEII), Atmos. Environ., 53, 177-185, 2012.

Ohara, T., Akimoto, H., Kurokawa, J., Horii, N., Yamaji, K., Yan, X., and Hayasaka, T.: An Asian emission inventory of anthropogenic emission sources for the period 1980-2020, Atmos. Chem. Phys., 7, 4419-4444, doi:10.5194/acp-7-4419-2007, 2007.

Pouliot, G., Pierce, T., Denier van der Gon, H., Schaap, M., Moran, M., and Nopmongcol, U.: Comparing emission inventories and model-ready emission datasets between Europe and North America for the AQMEII project, Atmos. Environ., 53, 414, doi:10.1016/j.atmosenv.2011.12.041, 2012.

Press, W. H., Teukolsky, S. A., Vetterling, W. T., and Flannery, B. P.: Numerical Recipies: the art of scientific computing, Cambridge University Press, New York, 1992.

Redington, A. L. and Derwent, R. G.: Calculation of sulphate and nitrate aerosol concentrations over Europe using a Lagrangian dispersion model. Atmos. Environ., 36, 4425-4439, doi:10.1016/S1352-2310(02)00420-X, 2002.

Reis, S., Skjøth, C. A., Vienoa, M., Geels, C., Steinle, S., Lang, M., and Sutton, M.: Why time and space matters - arguments for the improvement of temporal emission profiles for atmospheric dispersion modeling of air pollutant emissions, MODSIM2011 Congress, 12-16 December 2011, Perth, Australia http://www. mssanz.org.au/modsim2011/E1/reis.pdf, 2011.

Rolph, G. D., Draxler, R. R., and Pena, R. G.: Modeling sulfur concentrations and depositions in the United States during ANATEX, Atmos. Environ., 26, 73-93, 1992.

Rolph, G. D., Draxler, R. R., and Pena, R. G.: The use of modelderived and observed precipitation in long-term sulfur concentration and deposition modeling, Atmos. Environ., 27, 2017-2037, 1993.

Sakurai, T., Fujita, S. I., Hayami, H., and Furuhashi, N.: A study of atmospheric ammonia by means of modeling analysis in the Kanto region of Japan. Atmos. Environ., 39, 203-210, doi:10.1016/j.atmosenv.2004.09.051, 2005.

Seinfeld, J. H. and Pandis, S. N.: Atmospheric Chemistry and Physics: From Air Pollution to Climate Change, 2nd Edn., J. Wiley, New York, 2006.

Singles, R. J., Sutton, M. A., and Weston, K. J.: A multi-layer model to describe the atmospheric transport and deposition of ammonia in Great Britain, Atmos. Environ., 32, 393-399, doi:10.1016/S1352-2310(97)83467-X, 1998.

Sirois, A.: Temporal variation of oxides of sulphur and nitrogen in ambient air in eastern Canada: 1979-1994, Tellus, 49B, 270291, 1997.

Skjøth, C. A., Hertel, O., and Ellermann, T.: Use of the ACDEP trajectory model in the Danish nation-wide Background Monitoring Programme, Phys. Chem. Earth, 27, 1469-1477,
doi:10.1016/S1474-7065(02)00149-3, 2002.

Skjøth, C. A., Hertel, O., Gyldenkœrne, S., and Ellermann, T.: Implementing a dynamical ammonia emission parameterization in the large-scale air pollution model ACDEP, J. Geophys. Res., 109, D06306, doi:10.1029/2003JD003895, 2004.

Skjøth, C. A., Geels, C., Berge, H., Gyldenkœrne, S., Fagerli, H., Ellermann, T., Frohn, L. M., Christensen, J., Hansen, K. M., Hansen, K., and Hertel, O.: Spatial and temporal variations in ammonia emissions - a freely accessible model code for Europe, Atmos. Chem. Phys., 11, 5221-5236, doi:10.5194/acp-11-52212011, 2011.

Spellmann, J. W. and Hindmarsh, A. C.: GEARS: Solution of Ordinary Differential Equations Having a Sparse Jacobian Matrix, California University, Livermore Lawrence Livermore Laboratory, 41 pp., 1975.

Stein, A. F., Lamb, D., and Draxler, R. R.: Incorporation of detailed chemistry into a three-dimensional Lagrangian-Eulerian hybrid model: application to regional tropospheric ozone, Atmos. Environ., 34, 4361-4372, 2000.

Stelson, A. W., Friedlander, S. K., and Seinfeld, J. H.: A note on the equilibrium relationship between ammonia and nitric acid and particulate ammonium nitrate, Atmos. Environ., 13, 369-371, 1979.

Tesche, T. W., Morris, R., Tonnesen, G., McNally, D., Boylan, J., and Brewer, P.: CMAQ/CAMx annual 2002 performance evaluation over the eastern US, Atmos. Environ., 40, 4906-4919, 2006.

UNC: SMOKE V2.4 User's Manual, available at: http://www. smoke-model.org/version2.4/index.cfm (last access: 8 July 2012), 2009.

US EPA: Guidance on the use of models and other analysis for demonstrating attainment of air quality goals for ozone, $\mathrm{PM}_{2.5}$, and Regional Haze, US EPA, Research Triangle Park, NC 2771, 2007.

van Bremen, N., Burrough, P. A., Velthorst, E. J., van Dobben, H. F., de Wit, T., Ridder, T. B., and Reijnders, H. F. R.: Soil acidification from atmospheric ammonium sulphate in forest canopy throughfall, Nature, 299, 548-550, 1982.

van der Werf, G. R., Randerson, J. T., Giglio, L., Collatz, G. J., Kasibhatla, P. S., and Arellano Jr., A. F.: Interannual variability in global biomass burning emissions from 1997 to 2004, Atmos. Chem. Phys., 6, 3423-3441, doi:10.5194/acp-6-3423-2006, 2006.

Vet, R., Li, S.-M., Beaney, G., Belzer, W., Chan, E., Dann, T., Friesen, K., Hayden, K., Hou, A., Iqbal, S., Jones, K., Leithead, A., Liggio, J., Makar, P., Narayan, J., Ro, C.-U., Shaw, M., Sukloff, B., Vingarzan, R., and Qiu, W.: Chapter 6: Characterization of Ambient Ammonia, PM and Regional Deposition across Canada, in: Environment Canada, The 2008 Canadian Atmospheric Assessment of Agricultural Ammonia, Environment Canada, Gatineau, QC, Canada, 2008.

Wen, D., Lin, J. C., Meng, F., Gbor, P. K., He, Z., and Sloan, J. J.: Quantitative assessment of upstream source influences on total gaseous mercury observations in Ontario, Canada, Atmos. Chem. Phys., 11, 1405-1415, doi:10.5194/acp-11-1405-2011, 2011.

Wen, D., Lin, J. C., Millet, D. B., Stein, A. F., and Draxler, R. R.: A backward-time stochastic Lagrangian air quality model, Atmos. Environ., 54, 373-386, doi:10.1016/j.atmosenv.2012.02.042, 2012. 
Wesely, M. L.: Parameterization of surface resistance to gaseous dry deposition in regional-scale numerical models, Atmos. Environ., 23, 1293-1304, 1989.

Wexler, A. S. and Clegg, S. L.: Atmospheric aerosol models for systems including the ions $\mathrm{H}^{+}, \mathrm{NH}_{4}^{+}, \mathrm{Na}^{+}, \mathrm{SO}_{4}^{2-}$, $\mathrm{NO}_{3}^{-}, \mathrm{Cl}^{-}, \mathrm{Br}^{-}$, and $\mathrm{H}_{2} \mathrm{O}$, J. Geophys. Res., 107, 4207, doi:10.1029/2001JD000451, 2002.

Wu, S. Y., Hu, J. L., Zhang, Y., and Aneja, V. P.: Modeling atmospheric transport and fate of ammonia in North Carolina - Part II: Effect of ammonia emissions on fine particulate matter formation, Atmos. Environ., 42, 3437-3451, doi:10.1016/j.atmosenv.2007.04.022, 2008.

Zhang, L., Gong, S., Padro, J., and Barrie, L.: A size-segregated particle dry deposition scheme for an atmospheric aerosol module, Atmos. Environ., 35, 549-560, 2001.

Zhang, L., Moran, M., Makar, P., Brook, J., and Gong, S.: Modelling gaseous dry deposition in AURAMS: A Unified Regional Air-quality Modelling System, Atmos. Environ., 36, 537-560, 2002.
Zhang, L., Brook, J. R., and Vet, R.: A revised parameterization for gaseous dry deposition in air-quality models, Atmos. Chem. Phys., 3, 2067-2082, doi:10.5194/acp-3-2067-2003, 2003.

Zhang, L., Vet, R., Wiebe, A., Mihele, C., Sukloff, B., Chan, E., Moran, M. D., and Iqbal, S.: Characterization of the sizesegregated water-soluble inorganic ions at eight Canadian rural sites, Atmos. Chem. Phys., 8, 7133-7151, doi:10.5194/acp-87133-2008, 2008.

Zhang, X. Q. and McMurry, P. H.: Theoretical analysis of evaporative losses from impactor and filter deposits, Atmos. Environ., 21, 1779-1789, 1987.

Zhang, Y., Dore, A. J., Liu, X., and Zhang, F.: Simulation of nitrogen deposition in the North China Plain by the FRAME model, Biogeosciences, 8, 3319-3329, doi:10.5194/bgd-8-8161-2011, 2011. 